\title{
COMMENTS
}

\section{Solar Energy and Restrictive Covenants: The Conflict Between Public Policy and Private Zoning}

Reawakened interest in using the sun as an energy source is growing. ${ }^{1}$ A steadier and inore gradual increase has occurred in the utilization of private land use controls. ${ }^{2}$ There are indications of a brewing

1. Interest in solar energy is, of course, nothing new; the history of experiments using the sun's power goes back at least 2500 years. The earhest known use of this gift from the heavens was supposed to have occurred in about 700 B.C. in ancient Rome when the Vestal Virgins hit their alter fire with the 'pure fiame' of the sun. And in the third century, Archimedes, using a plane mirror reflector, is said to have set fire to Roman warships with the sun's beams. Much later, in 1621, the Von Tschernhaus burning apparatus, inade with convex glass lenses, was melting inetals. Still later, a printing press powered by the sun was described-and illustrated-in an article in the Sept. 21, 1882, issue of the British publication, Nature. . . .

Printing From Solar Power?, Berkeley Monthly, Oct. 5, 1978, at 51, col. 1.

The physical principle of the modern solar water heater was demonstrated by Horace de Saussure, an 18 th century naturalist, and in 1891 , the first U.S. commercial solar water heater was patented. Butti \& Perlin, Solar Water Heaters in California, 1891-1930, 15 CoEvolution Q. 4 (Fall 1977); D. Hayes, Rays of Hope: The Transition to a Post-Petroleum World 159-60 (1977) (crediting Nicolas de Saussure with earliest solar demonstration). Thirty per cent of the loones in Pasadena, Califorina had solar heating in 1897. Lovins, Soft Energy Technologies, 3 ANN. Rev. OF ENERgy 477, 489 (1978), reprinted in ENVT'L L. INST., SOLAR POLICY FOR THE 80's 177, 189 (1978). See also Butti \& Perlin, Solar Water Heaters in Florida 1923-1978, 17 CoEvoluTION Q. 74 (Spring 1978).

"Discoveries of oil fields [between 1920 and 1930] were the end of solar water lieaters." 15 CoEvolution Q. back cover (Fall 1977). See Butti \& Perlin, Solar Water Heaters in California, 1891-1930, supra, at 4 (infornation on turn-of-the-century California solar industry has largely been forgotten, but elderly people remeinber using solar water heaters 70 years ago).

The resurgence in interest has been very recent. See California ENergy Resources ConServation and Development Commission, Solar Energy in California: Residential Thermal Applications I-2 (staff draft report, Feb. 1978) [heremafter Cal. ENERgY Comm. REP.] ("The oldest of the current generation of California [solar] collectors is only three or four years old"); Executive Office of the President, Council on Environmental Quality, Solar Energy: Progress and Promise 11 (Apr. 1978) [hereinafter CEQ RePort] ("The number of houses suppleinented with solar energy lias increased froin roughly 30 in 1973 to somewhere in the thousands today"). But see J. KRENZ, ENERGY: Conversion AND UTILIZATION 212 (1976) (referring to "a prior period of high interest, the 1950's and the early 1960's"). Present interest in solar energy appears to be very high. See, e.g., The Coming Boom in Solar Energy, Bus. WEEK, Oct. 9, 1978, at 88 .

2. Hayes, Restrictive Covenants, in ENvT'L L. INST., SOLAR Policy FOR THE 80's 309 n.2 (1978) ("many or most single family homes built since World War II" are subject to restrictive covenants creating community associations with authority to disapprove exterior changes to house). See generally, Reichman, Residential Private Governments: An Introductory Survey, 43 U. CHI. L. Rev. 253 (1976). Although this postwar explosion in the use of covenants has inade these 
conflict between these two developments, as homeowners who wish to install solar equipment are inhibited by restrictive covenants encumbering their property. ${ }^{3}$

Scattercd examples from across the country indicate that homeowners who seek to install hoine solar heatimg systems-which require the use of plate-like solar collectors to absorb the sun's rays ${ }^{4}$-may be restrained froin doing so by neighbors unhappy with the collectors' appearance. 5 These neighbors are able to prevent solar installations be-

schemes a very common mode of private land use control, such use far predates this period. Commentators report that the running of a covenant restricting the use of land has been recognized as early as the thirteenth century. Newman \& Losey, Covenants Running with the Land, and Equitable Serviludes; Two Concepts or One? 21 Hastings L.J. 1319, 1319 (1970).

3. Hayes, supra note 2, at 309-10; Thomas, Solar Energy and the Law, in ENVT'L L. INST., Solar Policy FOR THE 80's 33, 47 (1978); Hayes, et al., Solar Access and Land Use, in ENVT'L L. Inst., Legal BaRriers to Solar Heating AND CoOling of BuIldings (1977), reprinted in ENVT'L L. INST., SOLAR POLICY FOR THE 80's 316, 331-32 (1978); Maullin \& Sheehy, Solar Rights in California, Envt'l Com., May 1978, at 7; R. Shoen \& A. Hirshberg, A Southern CALIForNia Gas Company Project Sage Report: Utilization Requirements (1978), prepared for the Southern California Gas Company by the Jet Propulsion Laboratory, California Institute of Technology, JPL Publication 77-49 at IV-7 (Jan. 1978); U.S. CoNGress, OFFICE OF TeChNOLOGY Assessment, Application of Solar Technology to Today's ENergy Needs 176-77 (June 1978) [heremafter OTA REPORT].

Private land use restrictions contained in property deeds are known by a variety of labels: restrictive covenants, real covenants, equitable servitudes, equitable restrietions, and mutual negative easements. Although the differences in terminology sometimes have been paralleled by differences in substantive rights, the modern trend is to treat deed restrictions as a simgle category. Stoebuck, Running Covenants: An Analytical Primer, 52 WASH. L. REv. 861, 863 (1977). This Comment will refer to all such arrangements as "restrictive covenants."

Restrictive covenants also can be used to promote solar energy development by guaranteeing homeowner access to sunlight. References to the rather extensive hiterature are collected in SoLAR ENERgy ReSEARCH INSTITUTE, SOLAR ENERgy LEGAL BIBLIOGRAPHY 87-108 (Interim Draft Report, Sept. 1978).

4. For a review of current solar technology, meluding a description of collector design and appearance, see BOOZ, ALLEN \& HAMILTON, INC., SOlar ENERGY UTILIZATION IN FLORIDA at app. A(23) (1975); California Energy Commission, Planning for Solar Access: A Primer 29-30 (1978); CAL. ENERgy COMM. ReP., supra note 1, at pt. I; EXeCUTIVE OFFICE OF THE PRESIDent, Solar Energy Policy Committee, Status Report on Solar Energy: Domestic Policy Review (Public Review Copy, Aug. 25, 1978) [hereinafter Domestic Policy Review]; FEDERAL ENERGY ADMINISTRATION, BuYING SolaR 1-14 (1976) (available from National Teclinical Information Service, PB-262-134, Report No. FEA/G-76/154); OTA REPORT, supra note 3, at $36-40,245-301$.

While there is high interest in "active" solar systems which involve the use of solar collector plates, prospects for an energy supply from "passive" solar use are equally promising and "passive" use is far less subject to the aesthetic conflicts examined here. For a recent definition of passive solar systems, see D. Bainbridge, The First Passive Solar Catalog 2 (1978).

5. See Kraye v. Old Orcliard Ass'n I, No. C 209453 (Cal. Super. Ct. for Los Angeles County, Mar. 1, 1979) (homeowner association decision to prohibit imstallation of visible solar collectors) (the author participated by contributing to the briefs of both the plaintiff's attorney and the state attorney general as amicus curiae); 1 SoLAR L. REP. 9-10, 20-22 (1979) (reporting conflicts in Arizona and Maryland); Hayes, supra note 2, at $309 \mathrm{n} .1$ (reporting conflicts in Anaheim and Palos Verdes, Cal.; Coral Gables, Fla.; Mystic, Conn.; Gaithersburg and Rockville, Md.; Albany, N.Y.; and Hollowell, Mn.). The United States Department of Housing and Urban Development 
cause of restrictive covenants contained in the homeowners' deeds. Such covenants soinetimes bar "appliances and installations" on roofs (or other property locations desirable as collector sites) if they are visible to neighbors. ${ }^{6}$ Alternatively, they may require that any exterior additions to homes be approved by a homeowners' association or architectural review committee. In several instances such groups have been unwilling to allow solar construction. ${ }^{7}$ Finally, more recently written covenants may impose explicit and severe restrictions upon solar collector placeinent. ${ }^{8}$

These restrictions are significant because of the importance which recently has been attached to the widespread use of solar energy. Commanding virtually no interest a decade ago, solar energy use now has become the "contemporary holy grail." 9 One result of this interest in solar energy has been a substantial government effort to speed its introduction as a major energy source through "commercialization" of the presently feasible forms of the new technology-primarily direct solar water heating installations which require solar collcctor panels. ${ }^{10}$

Due to a policy preference for marketplace allocation over direct government involvement, this "commercialization" program has been designed to rely upon consumer choice for effectuation. There are high

considers the covenant obstruction to solar development to be sufficiently serious to contract for proposed guidelines for its solution. Domestic Policy Review, supra note 4, at IV-20.

6. The relevant provision in the Kraye case stated: "In addition to the Architectural Control provided pursuant to Article VIII hereof, appliances or installations upon the roofs of structures shall not be permitted unless they are installed in such a manner that they are not visible from neighboring property or adjacent streets." Stipulation of Facts, at 3-4, Kraye v. Old Orchard Ass'n I, No. C 209453 (Cal. Super. Ct. for Los Angeles County, Mar. 1, 1979).

The point of provisions that incorporate the criterion of visibility appears to be strictly a concern with aesthetics. Solar installation requirements such as safety, on the other hand, are more appropriately and likely to be included in building codes. See Meeker, Building Codes as Barriers to Solar Heating and Cooling of Buildings, in ENVT'L L. INST., SOLAR POLICY FOR THE 80's 264, 288-89 (1978); Environmental Considerations, in Department of ENergy/Environmental Protection Agency, Solar Energy for Pacific Northwest ResiDential Heating, reprinted in ENVT'L L. INST., Solar Policy For the 80's 450, 468-73 (1978).

7. See note 5 supra.

8. Telephone interview with Mr. Marty Jaffe, Semior Research Associate, American Planning Association (1979).

9. Micliael Pertschuk, Chairman of the Federal Trade Commission, Welcoming Remarks, in Federal Trade Comm., The Solar Market: Proceedings of the Symposium on CompeTITION IN THE SOLAR ENERGY INDUSTRY 3 (1978). Solar energy has, in the words of none other than the American Petroleum Institute, "eclipsed apple pie and is giving Mom a close race for the title of the most popular platitude of the 'Seventies'." AMErican PETroleum Instirute, Supplementary Energy Sources 24 (1978). But see, No More Apple Pie, Sun Times, Mar. 1979, at 2 ("Once an apple pie and motherhood issue, solar has recently become the brunt of several critical articles and media campaigns").

10. Domestic Policy Review, supra note 4, at IV-2 - IV-3, IV-18 - IV-21. See CAI. ENERgY CoMm. ReP., supra note 1, at preface. See generally R. BEZDEK, et al., ANALYSIS OF Policy Options for ACcelerating Commerciallzation of Solar Heating and Cooling Systems (1977). 
barriers to mass consumer acceptance of solar heating systeins, however, in the form of high initial costs and lack of a proven performance record. " Consequently, if a speedy solar commercialization effort is to succeed, consumers with a high income and a willingness to take risks must support the critical initial stages of the prograin. ${ }^{12}$ Such affluent consumers are, unfortunately, the ones most apt to be restrained by the covenants at issue, for restrictive covenants are inost common in expensive planned developinents where an integrated overall appearance is considered one of the neighborhood's inost desirable features. ${ }^{13}$

Because of their innact on the inost likely consumers of solar energy, covenants restraining solar development may have an adverse social impact in two ways: first, by causing society to forego the direct enviroumental and social benefits from reducing depletable energy consuinption, and second, by creating impedinnents to the developinent of an important transitional inarket necessary to the solar industry's achievement of scale econounies and hence mass solar usage. The Califormia legislature believed the probleins sufficiently severe to justify declaring such covenants void. ${ }^{14}$ The private conflict thus is imbued with

11. Marylander Marketing Research, Inc., Solar Assisted Gas Energy: SAGEEvaluation of the Acceptability of the SAGE Concept, Study Conducted for Southern California Gas Company Project SAGE, at II-1, II-6 (1977); George Washington University, Solar Energy Incentives ANalysis: Psycho-Economic Factors Affecting the Decision Making of Consumers and the Technology Delivery System, prepared for the U.S. Dept. of Energy under Contract No. EX-76-6-101-2534 (1978). See Bezdek, Hirshberg \& Babcock, Economic Feasibility of Solar Water and Space Heating, 203 ScIENCE 1214 (March 23, 1979) (solar water heating economically competitive with electricity, but not with natural gas, in some regions of the country). It has been argued persuasively that the primary reason for solar energy's apparent cost disadvantage is the artificially low price of coinpeting energy sources. Id; Lovins, How to Finance the Energy Transition, in ENV'L L. INST., SOLAR POLICY FOR THE 80's 27, 29 (1978); CEQ REPORT, supra note 1 , at 36.

12. George Washington University Study, supra note 11, at 24-25; S. Feldman \& B. Anderson, Public Utility and Solar Energy Interface: An Assessment of Policy OpTIONS, prepared for U.S. Dep't of Energy Under Contract No. EX-76-5-01-2523, at 258-59 (1976).

13. A. Hirshberg \& E. Davis, Solar Energy in Bulldings: Implications for CaliForNia ENERGy POLICY 4-10 (1977).

14. California is the only state to date that has reacted to the problem with specific legislation. The California Civil Code provides that "any covenant, restriction, or condition contained in any deed, contract, security instrument, or other instrument affecting the transfer or sale of, or any interest in, real property which effectively prohibits or restricts the installation or use of a solar energy systein is void and unenforceable." CAL. Civ. CoDE $\$ 714$ (West Supp. 1979). The law goes on to except "reasonable" restrictions on solar energy systeins, which are defined as those restrictions "which do not significantly increase the cost of the system or significantly decrease its efficiency, or which allow for an alternative system of comparable cost and efficiency." Id. This statute is discussed in text accompanying notes 171-77 infra.

CAL. Crv. Code \$ 801.5(a) (West Supp. 1978) defines "solar energy systein" and includes passive solar designs within the scope of the definition. See note 4 supra. This has the effect of widening the law's impact beyond the sort of covenants discussed in this Comment. See text accounpanying notes 6-8 supra. For example, one reported potential application involved a covenant specifying a minimum square footage requirement for first floors. Telephone interview with Greg Wheatland, Staff Counsel, California Energy Commission (Feb. 1979). 
broader overtones.

This Comment will examme the appropriate common law resolution of such conflicts, ${ }^{15}$ finding that traditional notions of the appropriate judicial role in social policy implementation for the inost part preclude private attack on covenants. Although remedial doctrines may grant solar consumers some relief, it is concluded that only legislative action can impleinent a social policy favoring solar energy by preempting private covenants. A modified version of the California statute is advocated for adoption in other states.

\section{The Nature of the Conflict: Competing Policies}

The conflict examimed here-between the development of a socially desirable technology and the enforcement of private land use controls-is not new to the common law. It is important, however, that a clear understanding of the coinpeting interests underlying that conflict precede an exammation of the legal doctrines needed to resolve it.

\section{A. Public Policy: The Calls for a Solar Age}

The widespread interest in solar energy is an outgrowtli of the recent "energy crisis." "While inany disagree over the nature and source of this energy crisis, ${ }^{17}$ one widely held viewpomt is that "the diagnosis . . . is quite simple: deinand for energy is increasmg while supplies of oil and gas are diminishing." 18 The decreasing supply of petroleuin products-currently the inost widely used and versatile energy source-is thought crucial since it is believed to stem from an irreversi-

Although California is the only state that has addressed the covenant problem in legislation, in 1977, the city of Davis, California passed an ordinance annulling restrictive covenants prohibiting clothes lines, in an effort to promote this solar substitute for gas and electric clothes dryers. DAvis, CAL., CODE § 29-169.1 (1971 as amended).

15. This Comment assumes that the covenants are immune from attack on grounds other than their conflict with the solar policy.

16. Cf. R. Nelson, The Moon AND the Ghetto 116 (1977) ("The 1965 study Energy $R$ and $D$ and National Progress, whicls was undertaken with the express purpose of identifying sources of concern, reached the conclusion that significant shortages of conventional fuels, or sharply rising costs of extraction, were not likely in this century").

17. For an eloquent and mildly dispairing description of this philosophical split, see $C_{A L}$. Energy Resources Con. and Dev. Comm., 1 Biennial Rep.: Towards a California Energy Strategy: Policy Overview (1977). Compare D. Meadows, J. Randers, \& W. BehrENS, The Limits to Growth (1972) with The "Energy Crisis" Explained, Wall St. J. May 27, 1977 , at 10 , col. 1 .

18. President's National Energy Plan, reprinted in Energy Users Rep. Ref. File 21:1716 (1977). See also U.S. Is Guzzling More Gas, Oil Than It Can Replace In A Year, S.F. Chronicle, Apr. 10, 1978, at 9, col. 1. 
ble worldwide exhaustion of the resource. ${ }^{19}$ Some have also painted a bleak picture for the future availability of natural gas, ${ }^{20}$ which together with oil accounted for $80 \%$ of the total U.S. energy consumed in $1972 .{ }^{21}$

The implications of a reduced oil and gas supply are plain: the energy sources which now fuel the country will be insufficient in the future; the country inust develop alternatives. Unfortunately, serious and possibly prohibitive problems accompany every conventional energy supply option. ${ }^{22}$ As a result, so-called "exotic" nondepletable energy resources like solar radiation have assumed an unprecedented importance in the qucst to meet future energy needs. ${ }^{23}$

Availability, however, is only one aspect of the "cnergy crisis." Another is energy self-sufficiency. America's reliance on foreign energy sources, primarily petroleum, has increased gradually simce World War II, with a swift acceleration after 1970 - the year that doinestic

19. The principal oil-exporting countries will not be able to satisfy all the increases in demand expected to occur in the U.S. and other countries throughout the 1980's. . . . Within about four generations, the bulk of the world's supply of oil, created over hundreds of millions of years, will have been substantially consumed. . . . Obviously, high rates of growth of oil consumption sunply cannot be snstained.

President's National Energy Plan, reprinted in Energy Users Rep. Ref. File 21:0716 (1977). See also L. Brown, in Forward to D. HAyes, Rays of Hope: The Transition to a POST-PETROLEUM WORLD 9 (1977) ("The projected peaking and subsequent decline in the world production of petroleum . . . is only half a generation away"). Contra, Karpel, Ten Ways to Break OPEC, HARPER's MAG., Jan. 1979, at 65 (no reputable petroleum economist believes that a physical shortage of oil impends); Metz, Mexico: The Premier Oil Discovery in the Western Hemisphere, 202 SCIENCE 1261 (Dec. 22, 1978) (Mexican oil discoveries suggest that conventional wisdoin that most of the world's major oil fields have already been discovered may be "spectacularly wroug").

20. President's National Energy Plan, reprinted in Energy Users Rep. Ref. File 21:0716 (1977); Cal. Energy Resources Con. ANd Dev. Comm., 1 Biennial Rep.: Towards A California Energy Strategy: Policy Overview 56-57 (1977) ("The chances that all the supplemental gas projects proposed by the industry or considered necessary to provide an adequate gas supply to California will actually be completed, is nil") (emphasis in original). But see Concurrent Brief of the California Energy Commission, at 1-3, 142-90, Cal. Pub. Util. Comm. Case No. 10342 (May 30, 1978); 1001 Years of Natural Gas, Wall St. J., Apr. 27, 1977, at 20, col. 1.

21. J. KRENZ, supra note 1 , at 8.

22. See, e.g. D. HAYES, supra note 1, at 15-74 (1977). For this reason, energy couservation has gathered support as one of the most feasible, as well as cost-effective, energy strategies. See, e.g., Cal. Energy Resources Con. and Dev. Comm., 3 Biennial Rep.: Opportunities for ENERGY Conservation (1977).

23. There has been lively debate regarding the extent to which solar and other renewable sources can meet the nation's future energy demand. Solar's potential contribution to national cnergy needs in the year 2000 has been estimated froin 3 to 40 percent. Hayes, In the Lobby: Refiections on the Domestic Policy Review, Sun TImes, Oct. 1978, at 2. The Council on Environinental Quality controversially suggested 25 percent, CEQ REPORT, supra note 1, at iv-v, while Energy Secretary James Schlesinger, whoin few perceive as a solar advocate, considers 10 to 15 perccnt a "perfectly plausible" possibility, Interview with Secretary Schlesinger: "We Are Working on a New Solar Strategy," Bus. WeEx, Oct. 9, 1978, at 90, 91. See Robinson, American Physical Society Gives Long-Term Yes to Electricity from the Sun, 203 SCIENCE 629 (Feb. 16, 1979). 
production peaked. ${ }^{24}$ The costs and dangers of such reliance became vividly apparent during the 1974 embargo, and have been a source of concern ever since. ${ }^{25}$ The desire for self-sufficiency creates further imterest in energy sourccs like solar power that do not require any imports.

Along with the energy crisis, the increase in environmental awareness since the early 1970's is the major source of support for solar energy. Although they began independently, environmental awareness and interest in alternative energy sources were soon linked. As the Council on Environmental Quahty observed in 1976, "energy production and use are perhaps the most important determinants of environinental quality."26 One year earher, the Council remarked that the "impact of current energy technologies on the environment is well recognized. Emissions from energy resource extraction, conversion, and end use can and do cause substantial pollution." ${ }^{27}$ In contrast, "[1]ittle air or water pollution is associated with solar energy and, unlike other energy systems, the reactor is located a safe 93 million miles away." 28

For inany, then, the central lesson of increased energy and environmental awareness is that the nation "inust make a transition from an energy econouny based on rapid depletion of a fixed store of fossil fuels or environmentally unsound technology to one based primarily on current flows of energy from geotherinal, solar, and other renewable sources used in ways which produce minimum negative impact."'29

24. american Petroleum Institute, U.S. Energy: Yesterday, Today, and ToMORROW 6, 8 (1977).

25. See, e.g., The President's Address to Nation on National Energy Plan (Nov. 8, 1977), reprinted in 13 PRESIDENTIAL DocumENTS 1735, 1737 (1977) (quoting the Secretary of Defense as stating that "[t]he present deficiency of assured energy sources is the single surest threat . . . to our security and to that of our allies"); Department of Energy Organization Act of 1977, 42 U.S.C.A. \$ 7111(2) (Supp. 1977); Solar Energy Research, Development, and Demonstration Act of 1974, 42 U.S.C. § 5501(a)(7) (1976); Trans-Alaska Pipeline Act of 1973, 43 U.S.C. § 1651(a) (1976); Energy Reorganization Act of 1974, 42 U.S.C. \& 5801(a) (1976). This is one aspect of the energy situation upon which analysis seems to have reached a consensus. See, e.g., Oil and National Security, Wall St. J., Dec. 6, 1977, at 20, col. 1.

26. 7 Executive Office of the President, Council on Environmental Quality AnN. REP., ENVIRONMENTAL QUALITY 187 (1976).

27. 6 Executive Office of the President, Council on Environmental Quality AnN. REP., ENVIRONMENTAL QUALITY 426 (1975).

28. Cal. Energy Comm. Rep., supra note 1, at i. See 8 Executive Office of the PresiDENT, Council on ENvironmental Quality ANN. ReP., Environmental Quality 276, 290 (1977). But see Inhaber, Risk with Energy from Conventional and Nonconventional Sources, 203 SCIENCE 718, 720-23 (Feb. 23, 1979) ("nonconventional energy systems can have substantial risk to human health").

29. Cal. Energy Resources Con. and Dev. Comm., 3 Biennial Rep.: California EnERGY TRENDS AND CHOICES 17 (1977). Others, while less sangume about the speed with which nondepletable sources can be utilized, are nonetheless confident of "the inescapable conclusion that expotential growth of energy supply is couning to an end in the United States." Hayes, Energy Resources Available to the United States, 1985 to 2000, 203 SCIENCE 233, 239 (Jan. 19, 1979). 
Both the public and the private sectors have responded actively and coherently to this conclusion.

Federal actions have dominated the response, backed by a solar budget estimated at $\$ 718.4$ million in the 1979 fiscal year. ${ }^{30}$ Numerous federal laws have called for solar development. The Solar Heating and Cooling Deinonstration Act of $1974^{31}$ recites the virtues of solar energy $^{32}$ and states that it is the policy of the United States to "provide for the demonstration within a three-year period of the practical use of solar heating technology." 33 A congressional report on the Act observed that "[t] $]$ he purpose of this legislation is to stimulate in the shortest possible time the widespread commercial application of the teclinology for the solar heating and cooling of buildings."34 Other federal laws subsidize solar investments through tax provisions, ${ }^{35}$ provide secondary financing and loan insurance for solar energy systeins in liomes, ${ }^{36}$ call for the demonstration of solar energy in federal buildings, ${ }^{37}$ reinforce the commitment to solar researcli and developnient as a means of promoting its widespread use, ${ }^{38}$ and declare a general policy in favor of nondepletable energy sources. ${ }^{39}$ The commitment to these policies is buttressed by congressional language stressing the seriousness of the nation's energy problems and the consequent high priority to be placed on ameliorative measures. ${ }^{40}$ The present Administration has described solar energy as a "cornerstone" in the solution of the

30. U.S. DEP'T OF ENERGY, FY 1980 BUdGeT TO CONGRESS-BUdGeT Highlights (1978). For a description of the programs funded, see Domestic Policy Review, supra note 4, at § IV-1 IV-28; Federal TRADE Comm., supra note 9, pt. IV, $255-79$ (June 1978).

31. 42 U.S.C. $\S \S 5501-5517$ (1976).

32. Id. $\$ 5501$ (a).

33. Id. $\S 5501(\mathrm{~b})$.

34. JT. REP. No. 847, 93d Cong., 2d Sess. 2, reprinted in [1974] U.S. CODE CONG. \& AD. NEWS 5212, 5213.

35. Energy Tax Act of 1978, Pub. L. No. 95-618, § 101, 92 Stat. 3174 (1978) (to be codified in 26 U.S.C. § 44C). (1978)

36. National Energy Conservation Policy Act, Pub. L. No. 95-619, $\S \S 244-248,92$ Stat. 3206

37. Id. $\$ \S 544-551,92$ Stat. $3277-80$.

38. Solar Energy Research, Development, and Demonstration Act of 1974, 42 U.S.C. $\S 5551$ (1976). See S. REP. No. 1151, 93d Cong., 2d Sess. 1, reprinted in [1974] U.S. Code Cong. \& AD. NEwS 5915.

39. See, e.g., Department of Energy Organization Act of 1977, 42 U.S.C.A. $\$ 7112(6)$ (Supp. 1977); Energy Conservation Standards for New Buildings Act of 1976, 42 U.S.C. \& 6831(b)(2) (1976).

40. See Emergency Petroleum Allocation Act of 1973, 15 U.S.C. § 751(a) (1976); Geothermal Energy Research, Development, and Demonstration Act of 1974, 30 U.S.C. $\S 1101$ (1) (1976); Federal Nonnuclear Energy Researcl and Development Act of 1974, 42 U.S.C. $\$ 5901$ (1976) (\$ 5901(c): "The urgency of the Nation's energy challenge will require commitments similar to those undertaken in the Manhattan and Apollo projects . . . .); Department of Energy Organization Act of 1977, 42 U.S.C.A. § 7111(2) (Supp. 1977). 
nation's energy crisis ${ }^{41}$ - a "problem unprecedented in our history"42 requiring the "moral equivalent of war."43

States have also been active im the solar field. At least 32 states had enacted prosolar legislation as of early 1978.44 The more active states, such as California, have matched the vigor of the federal solar effort, given the relative size of their jurisidictions. ${ }^{45}$

Some local governments too have played an unusually active role, ${ }^{46}$ as have some utilities and financial imstitutions. ${ }^{47}$ Perhaps the most spectacular nongovernmental action was the observance of May 3, 1978 as "Sun Day," a privately organized demonstration of an estimated 25 million people im 35 countries supporting solar energy. ${ }^{48}$

Spurred by energy and environmental concerns, both traditional government sources of social policy and popular sentiment thus support the development of solar energy. Despite the strength and importance of this policy, liowever, only California has resolved authoritatively the conflict between solar development and the policy considerations favoring the enforcement of restrictive covenants. ${ }^{49}$

41. L. A. Times, May 4, 1978, at 1, col. 5, at 15, col. 3.

42. The Energy Problem, The President's Address to the Nation (Apr. 18, 1977), reprinted in 13 Presidential Documents 560 (1977).

43. Id. at 561. See also Fact Sheet on the President's National Energy Program, reprinted in 13 Presidential Documents 573 (1977); The President's Address on Energy to Joint Session of Congress (Apr. 20, 1977), reprinted in 13 Presidential Documents 566 (1977); The Environment: The President's Message to Congress (May 23, 1977), reprinted in 13 Presidential DocuMENTs 782 (1977); The President's Address to Nation on National Energy Plan (Nov. 8, 1977), reprinted in 13 PRESIDENTIAL DOCUMENTS 1735 (1977).

44. See Johnson, State Approaches to Solar Legislation: A Survey, 1 SolaR L. REP. 55 (1979). See also CAL. ENergy Comm. Rep., supra note 1, at app. VII-A, 67-93; Electric Power Committee, The Solar Energy Field, 11 Nat. Resources Law. 19 (1978); National Solar Heating and Cooling Information Center, State Solar Legislation (Jan. 1978).

45. See, e.g., CAL. Energy Comm. ReP., supra note 1; Hill, California Sees Itself as Leading Country to Era of Solar Energy, N.Y. Times, May 4, 1978, § B, at 7, col. 2.

46. See, e.g., Local Level Solar Activity, in ENVT'L L. INST., SOLAR POLICY FOR THE 80's 130 (1978); Motley, 'The Davis Experience": What It is, in ENVT'L L. INST., SOLAR POLICY FOR THE 80's 237 (1978).

47. See, e.g., Cal. Energy Comm. Rep., supra note 1, at IV-1 (terming California utihities "solar pacesetters"), at III-31 (describing program of San Diego Federal Savings and Loan Co.); We're Putting a Lot of Energy Into the Sun, S.F. Chronicle, May 1, 1978, at 11, col. 1 (advertisement by Pacific Gas \& Electric Co.); Letter from J.A. Carrera, Executive Vice President of Bank of America to Governor Edmond G. Brown, Jr. (Sept. 8, 1977) (By "develop[ing] throughout our branch banking service a capability for giving very good service to those seeking solar energy loans. . . , we are attempting to jump over the inarket shake-out period that usually accompanies a new technology").

48. Public solicitation letter from Denis Hayes, Chairman of Solar Lobby, received by author (1979). See, e.g., Energy Plea on Sun Day: Convert Dream to Reality, N.Y. Times, May 4, 1978 , at 1, col. 1 .

49. See note 14 supra. 


\section{B. Restrictive Covenants: The Strengths and Weaknesses of Private Directive Arrangements}

Deed covenants limiting the use of property are best understood as a variety of what Hart and Sacks term "private directive arrangeinents." 50 That is, they are one of the many ways by which people agree to order their affairs. ${ }^{51}$ Such extragovernmental arrangeinents, the source of inost organization in our society, establish ordered regimes of rules over time between the parties concerned. ${ }^{52}$ The common law systein places heavy reliance upon private directive arrangeinents to define a desirable social state..$^{53}$ As a consequence of this deep seated regard for decentralized ordering, private arrangeinents are legally. valid by presumption.

On a practical level, covenant arrangennents are an important ineans of ordering one aspect of the relationships of neighboring landowners. ${ }^{54}$ The actions of one party (e.g., a homeowner constructs a rooftop solar collector) that have an unfavorable effect upon others (neighbors see the collector and think it is ugly) will usually create disagreennent over whether to permit the action. ${ }^{55}$ An authoritative resolution of the conflict creates the right either to produce or to be free froin such effects, at least to some degree. ${ }^{56}$ Private covenant arrangements

50. H. Hart \& A. Sacks, The Legal Process: Basic Problems in the Making and APpLICATION OF LAW 124-60 (tent. ed. 1958).

51. See Schelling, On the Ecology of Micromotives, 25 PUB. INTEREST 59, 68 (1971).

52. See H. HART \& A. SACKs, supra note 50, at 210-12; L. Fuller \& M. EisenberG, Basic Contract Law ch. 2 (3d ed. 1972). Although the contract is the prototype, see Fuller, The Forms and Limits of Adjudication, 92 HARV. L. REV. 353, 363-64 (1978), private arrangements come in many forms: wills, deeds, leases, articles of incorporation, bonds, trusts, etc.

53. The covenant plan, for example, can be viewed as a means by which individual property owners aggregate to gain the desirable but otherwise privately unattainable group benefits of property value protection. R. POSNER, ECONOMIC ANAL YSIS OF LAW 49-51 (2d ed. 1977). This general deference to private interaction to achieve social goals is also reflected im welfare economics, see, e.g., H. VARIAN, MICROECONOMIC ANALYSIS ch. 5 (1978), and characterizes one approach to the economic perspective on legal analysis. See, e.g., Posner \& Rosenfeld, Impossibility and Related Doctrines in Contract Law: An Economic Analysis, 6 J. Legal Studies 83, 88 (1977) ("The process by which goods and services are shifted into their most valuable uses is one of voluntary exchange.").

54. This definition of permitted action has been described as determining an entitlement point. Polinski, Controlling Externalties and Protecting Entitlements: Property Right, Liability Rule, and Tax/Subsidy Approaches, 7 J. LEGAL STUDIES 1, 8 (1979).

55. Such effects are known as externalities. See, e.g., W. BAUMOL \& W. OATES, ThE THEory of Environmental Policy: Externalties, PUblic OutLays, and the Quality of Life chs. 1-3 (1975).

56. See Calabresi \& Melamed, Property Rights, Liability Rules, and Inalienability: One View of the Cathedral, 85 HARV. L. REv. 1089 (1972). While entitlements are unost commonly considered in absolute terms, such as a complete bar to solar development or an uninfringed right to construct solar devices, internediate solutions are an important possibility. An example of such a coinpromise would be to permit collectors, but only if they were suitably camouflaged. See note 72 infra. This is one possible interpretation of the California statute, supra note 14, which annuls only "unreasonable" covenant restrictions on solar development. 
represent one means of accomplishing the necessary definition of land use rights.

Courts uplold consensual definitions of rights both because of a moralistic desire to hold parties to their word and to prevent unjust enrichment, ${ }^{57}$ and because of the utilitarian belief that voluntary agreement enables the attainment of otherwise unobtainable mutual benefits. ${ }^{58}$ Despite these attractive features, however, restrictive covenants have certain congemital weaknesses that generally limit their authority, and which may prove especially troublesome in the context of a new technology like solar usage. Covenants, like all directive arrangeinents, must "speak from one poimt of time to another;",59 that is, they must attempt to resolve not only current conflicts but also those that will arise in the future. Because foresight is imperfect, information incomplete, and planning costly, arrangements cannot define future land rights in detail for all possible situations. ${ }^{60}$ The difficulty of interpreting such imprecise definitions of rights is coinpounded by the danger that the written terms may not reliably represent the parties' actual agreement about entitlement definition. The danger is peculiarly large in the case of covenants due to the way they are, created. In contrast with the contract paradigm where bargamed consent is ensured by each party's participation in the negotiation of terms, ${ }^{61}$ the parties bound by a covenant do not write its terms. Instead, its provisions express the preferences of a third party, the property developer. ${ }^{62}$ Also, parties

57. Unjust enrichment is a concern because covenant provisions which reflect the parties' entitlement understanding will influence the price at which the exchange takcs place. If a purchaser later appropriates rights that were not included in the original bundle, e.g., the right to develop property that was originally promised to be maintained as a pleasure garden, then the purchaser is unjustly enriched at the expense of the covenant's beneficiary. This was the situation in Tulk v. Moxhay, 2 Phil. 774, 41 Eng. Rep. 1143 (Ch. 1848), the groundbreaking Enghish case which established the doctrine of restrictions which "run with the land." See STOEBUCK, stpra note 3, at 887-90.

58. See National Soc'y of Professional Eng'rs v. United States, 98 S. Ct. 1355, 1363 (1978) (private contract law "establishes the enforceability of commercial agreements and enables coinpetitive markets-indeed, a competitive econony-to function effectively"); W. SHAKESPEARE, THE MERChANT OF VENICE act III, scene 3, lines 24-31 (stressing the importance of security of exchange). For a discussion of the importance of distinguishimg between these two grounds for enforcement, see Wellington, Common Law Rules and Constitutional Double Standards: Some Notes on Adjudication, 83 YALE L.J. 221, 222-29 (1973).

59. H. HART \& A. SACKS, supra note 50, at 124-25.

60. For a discussion of this pervasive problein of "bounded rationality" in private arrangements, see O. WILliamson, MARKETS AND HiERARCHIES: ANALYSIS AND ANTITRUST IMPLICATIONS 65-67 (1975). See also Joskow, Commercial Impossibility, the Uranium Market and the Westinghouse Case, 6 J. LEGAL STUdIES 119, $157-58$ (1977).

61. See Fuller, supra note 52, at 363-64.

62. Consigny \& Zile, Use of Restrictive Covcnants in a Rapidly Urbanizing Area (pt. 1), 1958 W1SC. L. REv. 612, 620-36. For a rather extrene illustration of such property developer expression, see J. MCPHEE, ENCOUNTERS WITH THE ARCHDRuid 87-96 (1971). As a result, such previously established provisions may share in some cases the problems which accompany "adhesion 
binding themselves to an arrangement regime often do not focus on its terms, smce the primary exchange is of the land and fixtures. The covenant terms may be an ancillary, sometimes even ignored, aspect of the property rights transferred. ${ }^{63}$

Although this concern with consent, drawn froin contract law, is not the sole consideration determining covenant enforcement, ${ }^{64}$ it is significant in determining the scope given to mstruments of this nature. Since covenants are interpreted according to the joint intent of the grantors and the grantees ${ }^{65}$ at the time the deed was made, ${ }^{66}$ one can argue that the novelty of solar devices should remove thein from a proper interpretation of the covenants' proscription. ${ }^{67}$ The origmal target of the covenants (e.g., air conditioners, television and radio antennae) all could be placed in alternative locations; ${ }^{68}$ the covenant had a regulatory nature. In contrast, the effect becomes prohibitory when applied to most solar devices since roofs are frequently the only feasible location for such collectors. ${ }^{69}$ Because such a prohibition increases the burden of the covenant beyond the original expectations of any party, the arguinent concludes, the covenant ought not be interpreted to proscribe new technologies like solar collectors. ${ }^{70}$

contracts." See Kessler, Contracts of Adhesion-Some Thoughts About Freedom of Contract, 43 Colum. L. Rev. 629 (1943).

Commentators have observed that market forces generally will prompt developers who draft covenants to do so in an efficient manner. E.g., Ellickson, Alternatives to Zoning: Covenants, Nuisance Rules, and Fines as Land Use Controls, 40 U. CHI. L. REV. 681, 713 (1973). But the same factors which "bound" rationality, see O. WILLIAMSON, supra note 60 , will attenuate market discipline of the vcry undefined or disputed details which lead to hitigation about restrictive covenants.

63. Note, Validity Rules Concerning Public Zoning and Private Covenants: A Comparison and Critigue, 39 So. CAL. L. REv. 409, 434-36 (1966); Consigny \& Zile, supra note 62.

64. See generally Callaway, Enforcemcnt of Restrictive Covenants in Tract Developments, 3 HAST. L.J. 50, 51-57 (1951); Reno, The Enforcement of Equitable Servitudes in Land: Part I, 28 VA. L. REV. 951, 972-78 (1942).

65. E.g., Martin v. Holın, 197 Cal. 733, 742, 242 P. 718, 722 (1925).

66. E.g., Gamble v. Fierman, 82 Cal. App. 180, 182, 255 P. 269, 270 (3d Dist. 1927). See Cal. Civ. Code $§ 1647$ (West 1973); Restatement of Property $§ 246$ (1940); 2 American Law of Property § 8.65 (A.J. Casner ed. 1952).

67. Since parties to a covenant probably do not understand the covenant's scope, judicial efforts at determining the "intent of the parties" mnst rely to some degree on common sense, which asked not "what the parties 'really' meant, but what treatment is appropriate given the purposes that are objectively revealed." Eisenberg, Private Ordering Through Negotiation: Dispute-Settlement and Rulemaking, 89 HARv. L. REv. 637, 671 (1976).

68. Rooftop air conditioners could be window mounted or centrally installed. Anteunae could be strung in attics, placed on top of sets, or replaced by cable.

69. In Kraye v. Old Orchard Ass'n I, No. C 209453 (Cal. Super. Ct. for Los Angeles County, Mar. 1, 1979), the parties stipulated that no alternative placements for the solar device were possible. While alternative locations for solar devices might sometimes exist, an urban or a suburban dweller seeking to install solar heating probably will have hittle choice of location.

70. Two factors limit the persuasiveness of this argument. First, the argument could not be applied to covenants which specifically restrict solar devices. Second, an argument based on consumer ignorance could not reasonably apply to purchases made after consumers know about solar 
This attempt to interpret away the covenant restrictions fails, however. Solar collectors may create exactly the aesthetic conflict that the covenants were adopted to resolve. ${ }^{71}$ To completely discount the aesthetic interests of surrounding homeowners-as occurs if solar development is exempted from covenant restraints-is unfair, especially when mexpensive coinpromise actions may make it possible to satisfy all parties. $^{72}$ Finally, although covenants regarding roof or yard additions may have had a narrow scope of operation originally, the same is not true of provisions establishing governing homeowners associations or architectural review boards. Simce both parties almost certainly understood committee approval provisions as estabhshing a flexible and democratic ineans of dispute resolution, even for unforeseen disputes, there is no reasonable complaint against binding the buyer-who purchased property subject to group management of such affairs-to the will of the group, which of course may still decide to permit such uses. $^{73}$

Restrictive covenants are thus an important private means of settling land use conflicts. While a special sensitivity to potential definitional inaccuracy is warranted generally, novelty of a technology alone is insufficient to overturn covenant provisions.

The provisions are not necessarily immune from attack, however. Judicially recognized public policies have overturned restrictive covenants. The possibility of such a public policy protecting solar development is explored in the following section.

\section{II}

\section{The Use of Social Policy to Adjust Private Arrangements: The Public Policy Doctrine}

One means available to the courts for resolving the conflict between solar development and neighborhood land regulation is the use of the public policy doctrine. Under that doctrine, courts occasionally refuse to enforce covenant arrangements or other private agreements ${ }^{74}$

devices. This Comment does not attempt to assess what consumers can be expected to know at the present time.

71. Cf., e.g., Petersen v. Friedman, 162 Cal. App. 2d 245, 328 P.2d 264 (1st Dist. 1958) (television antennae barred by an existing easement of view although easement was created before television had been imvented); La Vielle v. Seay, 412 S.W.2d 587 (Ky. 1966) (existence or nonexistence of technology when covenant created held irrelevant).

72. Depending on property configuration, architectural design, and type of solar technology, the visual impact of solar collectors and related equipment possibly can be reduced. Canouflage measures frequently will be impossible, however. Hayes, supra note 2, at 310.

73. But see note 147 and accompanying text infra.

74. E.g., 6A A. Corbin, Contracts pt. 8 passim (1962); 14 S. Williston, Contracts chs. 48-52 (3d ed. 1972). 
that violate some social interest the court finds paramount. For example, on the strength of a nonstatutory policy agamst restramts of trade, courts have refused to enforce deed restrictions on liquor sales which were part of a sclieme to create a monopoly. ${ }^{75}$ This section will ex- . amine the way in which courts apply public policy in suits involving private directive arrangements, and will analyze the legitimacy of various sources of public policy. Fmally, this section will consider whether the public policy doctrine is useful im resolving the conflict at issue in this Comment.

\section{A. Judicial Application of the Public Policy Doctrine: A Doctrine Without a Theory}

No one has ever accused the public policy doctrine of clarity. Judges and cominentators lave been trying to define concretely the doctrine for a long time, but the results of their efforts are not very satisfying. ${ }^{76}$ These definitional difficulties have resulted in a remarkable number of judicial warnings against the perils of overusing the doctrine. ${ }^{77}$ In the absence of a general understanding of the doctrine's scope, this anxiety is understandable, for without principled limits the

75. Burdell v. Grandi, 152 Cal. 376, 92 P. 1022 (1907). Courts have used public policy grounds to void deed restrictions since at least 1641. See Winfield, Public Policy in the English Common Law, 42 HaRv. L. Rev. 76, 83 (1928). More inodern and better known examples have overturned racially restrictive covenants, on both constitutional and inore general "public policy" grounds. Shelley v. Kraemer, 334 U.S. 1 (1948) (constitutional grounds); Hurd v. Hodge, 334 U.S. 24, 34-35 (1948) (public policy grounds).

76. Corpus Juris Secundum describes public policy as "the principles under which freedoin of contract or private dealing is restricted by law for the good of the community." 72 C.J.S. Policy 212 (1951); cited in Petermann v. International Bhd. of Teamsters, 174 Cal. App. 2d 184, 188, 344 P.2d 25, 27 (2d Dist. 1959). Story's definition is similar: "By 'public policy' is intended that principle of law which holds that no citizen can lawfully do that which has a tendency to be injurious to the public or against the public good." W. STORY, CONTRACTS $\$ 546$ (2d ed. 1847), quoted in Safeway Stores v. Retail Clerks Etc. Ass'n, 41 Cal. 2d 567, 575, 261 P.2d 721, 726 (1953). In essence, both stateinents say little other than that "public policy means doing the right thing." A factory discharging pollution within legal emission standards and a tacky pink house in an unrestricted but otherwise consistently beautiful neighborhood both inay injure the public good, yet no one thinks to attack thein on the basis of the public policy doctrine. Similar objections accoinpany other attempts at a general definition. E.g., E. Greenhood, The Doctrine of Public Policy in the LAw of Contracts, Reduced to Rules (1886). See also Nutting, Suggested Limitations of the Public Policy Doctrine, 19 MinN. L. REv. 196, 199 (1935) ("A prayerful examination of the cases in an atteinpt to learn what public policy is [in the conflicts field] has caused this investigator to retire baffled, which seems a not unusual result").

The present analysis will not consider the "public policy doctrine" as it appears in the conflict of laws field, although relevant observations made in that area will be noted. For an insightful analysis of the choice of law/public policy doctrine, see Paulsen \& Sovern, "Public Policy" in the Conflict of Laws, 56 CoLuM. L. REv. 969 (1956).

77. Any assessinent of the possible influence of the doctrine of public policy inust take account of the marked reluctance to make use of it which has now becoine a feature of the English judicial utterance. I do not think that practice altogether accords with protestation. But certainly, so far as protestation goes, the current has been running strongly for over a hundred years. 
doctrine creates a potential for unbridled judicial discretion. ${ }^{78}$ As a consequence, "there has been a noticeable tendency to regard public policy as a last resort for molding the law."79 Nonetheless, the doctrine is still quite alive today. ${ }^{80}$

Clear definition of public policy is often hampered by the misleading idea that "public pohcy" is a unitary force which could be represented by a smgle definition. ${ }^{81}$ In actuality, "public policy" stands for a great number of propositions, ${ }^{82}$ so there is not one public policy; there are inany. Moreover, as seen above, ${ }^{83}$ other policy considerations favor the usual conflict resolution (e.g., enforcement of the covenant) which would result without the "public policy" doctrine. ${ }^{84}$ Thus, the essential dynamic of the doctrine inust be to balance the weights of competing policies rather than to search for a policy of "public" status which, once discovered, would immediately trunp usual considerations. ${ }^{85}$

C. RADClifFe, The LAW AND ITs Compass $45-46$ (1960). Cf. Winfield, supra note 75, at 91 ("The attitude of the bench in general toward public policy is one of cautious acceptance of it.").

78. It is the province of the statesinan, and not the lawyer, to discuss, and of the Lcgislature to determine what is best for the public good and to provide for it by proper enactment. It is the province of the judge to expound the law only . . . not to speculate what is best in his opinion for the advantage of the community.

Egerton v. Brownlow, 4 H.L. Cas. 1 (1853) (opinion of Baron Parke). See also Nutting, supra note 76, at 198. For an unusually complete collection of warnings, see National Auto Ins. Co. v. Winter, 58 Cal. App. 2d 11, 136 P.2d 22 (3d Dist. 1943).

79. Winfield, supra note 75 , at 98 .

80. See, e.g., Gas Light Co. v. Georgia Power Co., 225 Ga. 851, 171 S.E.2d 615 (1969); Lain v. Rennert, 308 Ill. App. 572, 32 N.E.2d 375 (1941); Dixon v. Van Sweringen Co., 121 Ohio St. 56, 166 N.E. 887 (1929). See notes $74-76$ supra and note 85 infra.

While frequently invoked by hitigants, the public policy doctrine is seldom relied upon by courts. See, eg., Glickman v. Collins, 13 Cal. 3d 852, 120 Cal. Rptr. 76, 533 P.2d 204 (1975); Crail v. Blakely, 8 Cal. 3d 744, 106 Cal. Rptr. 187, 505 P.2d 1027 (1973).

81. One manifestation of this is that "public policy" is always singular in commentators' discussion of the doctrine. See, e.g., Winfield, supra note 75, at 96-97.

82. [Rlightly or wrongly, considerations of public policy have been invoked by Enghisl judges in a great many contexts and for a great many purposes. Not to make any exliaustive list, I can bring to mind decisions about the public service and the admimistration of public affairs, about the inalienability of property, about the benefits arising froun crime, about ousting the jurisdiction of the court, about sexual immorality, about stiffing criminal prosecutions and newspaper criticisıns, about not plowing up farm land, and, for that matter, about lolding churcli services "according to the true tine of the sun." And to these one unust add the well-known lieads, to which Baron Parke refers, of restraints of trade and restraints of marriage.

C. RADCLIFF, supra note 77, at 50. See also Winfield, supra note 75, at 85-86 ("Public policy, like misery, made sone very incongruous bedfellows."). Note that "public policy" also varies over time. E.g., id. at 94; C. RADCLIFFE, supra note 77, at 41-43.

83. See text accompanying notes 50-73, supra.

84. See H. Hart \& A. SaCks, supra note 50, at 166-67; Restatement (SeCOND) OF CoNTRACTS § 320 (Tent. Draft No. 12, May 1977).

85. The balancing dynamic may be observed in those individual "public policies" whicl are of sufficient vintage to be regarded as doctrines in their own right. One example is the public policy against restraints of trade. "Clearly established" in common law by 1711 , Winfield, supra note 75 , at 85 , this policy las rccognized the importance of competing considerations by reversing only unreasonable private arrangements. See Hall v. American Oil Co., 504 S.W.2d 313, 318 (Mo. 
The public policy doctrine thus is viewed correctly not as a substantive rule, principle, or policy, but rather as a way of generating $a$ rule that will control a particular case. It is a rule about rules, or what Hart describes as a "secondary rule." 86 This secondary rule instructs a judge to balance coinpeting considerations, an activity which is well within the judicial ken.

Why, then, has the doctrine inspired such an unmistakable judicial wariness? First, judges are plagued by the lack of substantive commonality between public policy cases, which means that the force of stare decisis cannot operate in the usual fashion. ${ }^{87}$ And there is a related error of attempting to satisfy the desire for doctrinal limits by reducing the doctrine to a series of substantive rules, ${ }^{88}$ a problem caused by a

App. 1973) (quoting Skrainka v. Scharringhausen, 8 Mo. App. 522, 525 (1880)). It thus has been observed that:

in dealing with covenants in restraint of trade the judges have shown themselves willing and competent to balance conflicting social and economic interests, both of the parties and more recently of the public; and to weigh the reasonableness of the expectations of the parties, the interests they seek to protect, and the means proposed for domg so.

Shand, Unblinkering the Unruly Horse: Public Policy in the Law of Contract, 30 CAMB. L.J. 144, 167 (1972) (einphasis in original). See also Doo v. Packwood, 265 Cal. App. 2d 752, 71 Cal. Rptr. 477 (5th Dist. 1968). A strikingly similar "unreasonableness" limitation is likewise placed on the ancient policy agamst restraints on alienation. See, e.g., Carneal v. Kendig, 96 Va. 605, 85 S.E.2d 235, 237 (1955).

Less established policies do not explicitly proclaim their balancing nature, but the characteristic is shown by differing results that can only be explained in terms of competition between policies of differing weights. For example, in Eyennan v. Mercantile Trust Co., 524 S.W.2d 210, 217 (Mo. 1975), a will provision specifying that a house be demolished was overturned upon the public policy against "senseless destruction serving no apparent good purpose." It seems clear, however, that the homeowner could have accomplished the same destruction-without legal interference-if she had ordered the house razed during her lifetime. The difference in result can only be explained by the greater policy weight in favor of enforcing contracts as compared to the policy of enforcing wills. See H. HART \& A. SACKs, supra note 50, at 149; Furmston, The Analysis of Illegal Contracts, 16 U. ToRONTO L.J. 267, 303 (1966).

In applying the public pohcy doctrine, then, it is important to consider explicitly the force of the opposing considerations rather than to search for a conclusory "public policy". See Sliand, supra at 157-58, 162, 165; Gellhorn, Contracts and Public Policy, 35 Colum. L. Rev. 679, 687-88, 690 (1935). See also The Kensington, 183 U.S. 263, 269 (1902), quoted in Paulsen \& Sovern, supra note 76, at 993 (illustration of conclusory reasoning in the conflicts field).

86. H.L.A. HART, THE CONCEPT OF LAW 89-96 (1961).

87. See note 82 and accompanying text supra. While specific policies with venerable comnon law roots, such as restraint of trade or restraint upon alienation, have benefited froin such typical common law developinent, see note 85 supra, this is not true for newly proposed or rarely invoked policies. Llewellyn implicitly poimted out the weakness of such cases:

[N]o case can have meaning by itself. Standing alone it gives you no gindance as to low far it carries, as to low much of its language will hold water later. What counts, what gives you leads, what gives you sureness, that is the background of other cases in relation to which you must read the one. They color the language, the technical terms, used in the opimion. But above all they give you the wherewithal to find of which of the facts are significant, and how far the rules laid down are to be trusted.

K. Llewellyn, The Bramble Bush 49 (1951) (einphasis in original).

88. See Furmston, supra note 85 , at 308 (many public policy cases lave an unquestionable result, but are unconvincingly explained, partly beeause commentators have overgeneralized- 
judicial misapprehension of the doctrine as a product rather than a process. But these problems, while important, only hint at the basic issue raised by the doctrine: the definition of the appropriate role for the judiciary in the determination and application of social policy.

\section{B. Limits of the Public Policy Doctrine}

Traditional definitions of public policy assign judges the problem of deciding when private arrangemcnts "violate some statute, or [are] contrary to judicial decision, or [are] against public health, morals, safety or welfare, or [are] in some forn imjurious to the public good."89 This is a tall order. A doctrine giving courts free rein to make decisions about the "public good" raises an obvious question of appropriate limits.

The behef that the determination and implementation of most social policies is a "legislative" function, hence mappropriate for courts, hes at the heart of inuch of the judicial disquiet surrounding the public policy doctrine. ${ }^{90}$ The problem is to distinguish between improper

and thus oversimplified-the effect of these cases); Shand, supra note 85, at 158-59. Observe that the full title of an elderly hombook on the topic is E. GREENHOoD, THE Doctrine of PUBLIC Policy in the Law of Contracts, Reduced to Rules (1886). In this hight, consider the remark of Paulsen \& Sovern, supra note 76, at 1162, that the "principle vice of the public policy concepts is that they provide a substitute for analysis. The concepts stand in the way of careful thought, of discriminating distinctions, and of true policy development."

89. Dixon v. Van Sweringen Co., 121 Ohio St. 56, 166 N.E. 887 (1929).

90. See Winfield, supra note 75 , at 89 . The idea that courts should not engage in "legislative" activities is comparatively recent. Although medieval monarchs did make laws and while much of the early common law was founded on statute, policymaking in the sense of conscious decision about and implementation of collective goals was not a dommant activity of either courts or other branches of government in medieval times. Rather, judicially determined standards of morality dominated the settleinent of private controversies. Shand, supra note 85, at 150, 154. Though the Revolution of 1688 more fully assured.that Parliament spoke with authority equal to that of the courts, Winfield, supra note 75 , at 89 , courts long continued to regard legislative expressions with hostility as imtrusions upon judicial authority, as illustrated by the rule that statutes in derogation of the common law were to be construed strictly. See Landis, Statutes and the Sources of Law, in HARVARD LEGaL Essays 217 (1934).

The rise of the modern legislature radically revised this view by "at least nouninally [relegating judgesl to the role of interstitialists" who work the occasional area left untrod by the active lawmaking asseinbly. Gellhorn, supra note 85 , at 579 . According to at least one observer, this shift has been fundamental, turnimg primary judicial attention away from common law sources towards a preoccupation with the supplementary elaboration of statutes. M. SHAPIRO, THE Supreme Court AND Administrative AGencies 23 (1969). This increasing legislative deference has clashed with the historically open-ended breadth of the public policy doctrine, causing it to be delimited by an increasingly cautious rhetoric. See Winfield, supra note 74, at 83-84, 86 .

Iromically, judicial acknowledgment of the subservience and limitation of the judicial role has coimcided with the rise of an activist and policy-conscious American judicature, see M. HorwITz, THe TrANSFORMATION OF AMERICAN LAw, 1780-1860 30 (1977), a rise which today appears to be accelerating. See D. Horowitz, The CourTs And Social Policy 19-20 (1977); Chayes, The Role of the Judge in Public Law Litigation, 89 HARV. L. REv. 1281 (1976). Nevertheless, the modern "nonlegislative" concept of the judicial role eertainly servcs to some degree as a selfimposed constraimt on the behavior of courts. 
"legislative" and proper judicial actions. While it may be easy to agree that at some point the public policy doctrine can cxpand the judicial role unacceptably, there has been no accord on this appropriate limit.

The extent of controversy is illustrated by the diversity of commentators' opinions. One view of the limit of "acceptable" use of the doctrine is that any use of policy-in the sense of "guarding and forwarding the material interests of society"-should be forbidden. ${ }^{91}$ The opposite opinion is that the doctrine appropriately represents a frank "principle of judicial legislation or interpretation founded on the current needs of the community"92 to be gathered from the opinions of judges as "inen of the world, as distinguished froin opinions based on legal learning." $" 93$ Such disagreencnt is not surprising, since opinions on this inatter reflect larger views about the appropriate social and political role of the judiciary. Unless one consistent perspective can be inade to dommate this perennially debated area, then, little accord can be expected to greet any particular grand view of the public policy doctrine.

This does not inean that judicial receptivity to solar commercialization under the public policy doctrine is unpredictably reliant on capricious personal opinions. Disagreements on abstract jurisprudential planes can be accompanied by accord on particular questions. In order to determine if the use of the solar policy is within such a realm, one must examine past policies employed under the public policy doctrine for relevant consistencies.

Although "typologies of policy issues are almost as numerous as the writers about them," 94 one cominon feature of the policies invoked under the public policy doctrine is their moralistic nature. ${ }^{95}$ Prohibition of government conflict of interest contracts, ${ }^{96}$ animosity towards agreeınents "in derogation of marriage," $" 97$ and lostility to contracts leading to "fraud, prostitution, crime, oppression, and infidelity"

91. C. RADCLIFFE, supra note 77 , at 63-64.

92. Winfield, supra note 75 , at 92.

93. Rodriguez v. Speyer Bros., [1919] A.C. 59, 79, quoted in Winfield, supra note 75, at 97. Cf. Holmes, Common Carriers and the Common Law, 13 AM. L. Rev. 609, 630-31 (1879) ("The very considerations which the courts most rarely mention, and always with an apology, are the secret root from which the law draws all the juices of life. We mean, of course, considerations of what is expedient for the community concerned."). For a review of attempted distinctions between "acceptable" and "unacceptable" policies, see Gellhorn, supra note 85, at 683.

94. D. HoROwIT, supra note 90 , at 57.

95. See, e.g., C. RADCLIFFE, supra note 77, at 65-66.

96. Halliday v. Norfolk \& W. Ry., 44 Ohio L. Abs. 208, 213-14 (1945) ("It is contrary to good morals and public policy to permit a municipal officer to enter into contractual relations with a muricipality of which he is an officer.").

97. 6A A. Corbin, Contracts $\$ 1474$ (1951).

98. E. GREENHOOD, supra note 76 , at 136. 
have an unmistakable moral tone. ${ }^{99}$

A similar moralistic approach has appeared when recent commentary has souglit to distmguish between those cases that are properly within the judicial role and those that are not. Drawing on the semmal statement and Hart and Sacks, ${ }^{100}$ Professor Ronald Dworkin nnakes a distinction between principles and policies. Dworkin defines a principle as "a standard to be observed, not because it will advance or secure an economic, pqhitical, or social situation deemed desirable, but because it is a requirement of justice or fairness or some other dimension of morality." 101 Thus "arguments of principle justify a political decision by sliowing that the decision respects or secures some individual or group right." 102 In contrast, a policy is "that kind of standard that sets out a goal to be reached, generally an improveinent in soine economic, political, or social feature of the commumity . . .."103 Correspondingly, "arguments of policy justify a political decision by showing that the decision advances or protects some collective goal of the community as a whole."104

Dworkin distinguishes between justifications based on norality and those based on efficiency as a prelude to arguing that only the former are acceptable for adjudication. He looks to inorality for principles which indicate that a party has a right to win a law suit. Decisions justified by principles neither require assessments of "the nature and intensity of different demands and concerns distributed throughout the commumity, ${ }^{\prime 105}$ nor are liable to unfairly surprise the losing party. ${ }^{106}$ Principle-based adjudication, therefore, is essential to ensure that judi-

99. The one great common law public policy that appears to be an exception to this moralistic orientation is the policy against restraints of trade, whicl seems concerned with economic efficiency. An examination of this doctrine, however, indicates that it "originated not with notions of competition and protection of the free market, but rather in support of 'fair' commercial activity and of crumbling guild customs." E. GELLHORN, ANTITRUST LAW AND ECONOMICs IN A NUTSHELL 4 (1976).

100. See H. HART \& A. SACKS, supra note 50, at 159. Hart and Sacks noted the distimction but largely failed to make anything of it. Id. at 160-68. See also Pound, Survey of the Conference Problems, 14 U. CiN. L. Rev. 324, 328-32 (1940).

101. R. DWorkin, Takng Rights SERJously 22 (1977).

102. Id. at 82. See also Wellington, supra note 58, at 256.

103. R. DWORKIN, supra note 101, at 22.

104. Id. at 82. In making this saine distinction, Wellington, supra note 58, implies that the defining characteristic of policy justification is its reliance upon ins/rumental reasoning. Id. at 22324. Instrumental reasoning is the "selection of efficacious means to previously given ends" or "that form of rationality whieh seeks to discriminate annong alternative actions by assessing their coinparative tendency to advance or retard the achievement of the actor's goals or values." Tribe, Technology Assessment and the Fourth Discontinuity: The Limits of Instrumental Rationality, 46 So. CAL. L. REv. 617, 618 (1973) (emphasis deleted).

105. R. DworkIN, supra note 101, at 85.

106. Id. at 86. 


\section{cial decisions are fair ${ }^{107}$ and consistent. ${ }^{108}$}

Judicial judgments based on instrumental policy justifications, on the other hand, are not necessarily fair to the parties before the court; aimed at achieving the best for the community, they inay benefit the whole at the expense of some of the members. If the apphication of a policy inust involve such give and take, then Dworkin asserts that those making such amoral goal-oriented decisions ought to be accountable. Therefore, judges should leave such issues to the legislature. ${ }^{109}$

As noted above, ${ }^{110}$ sound economic, political, and environmental reasons lie behind the large recent commitment to solar development. But it is social policy ${ }^{111}$ rather than a moral judgment of right and wrong that motivates the commitment. ${ }^{112}$ Consequently, if one accepts Dworkin's reasonimg, a judicial abrogation of a private directive arrangeinent on the grounds that it interfered with the achievement of this collective social goal would appear indeed to be an unacceptably "legislative" judicial action. This view is consistent with judicial application of the public policy doctrine, since there is no precedent for its application in support of the kind of amoral socio-economic judgments inherent in a policy favoring solar developinent. ${ }^{113}$

107. Wellington shares this concern for fairness. He reasons that courts have a high relative competence to determine principles (which stem from society's conventional morahity), and that fair judicial reasoning usually must proceed from moralistic principles just as judicial interpretation of documents must proceed from the document. Wellington, supra note 58, at 243-49. But see Mercoid Corp. v. Mid-Contment Co., 320 U.S. 661, 672-74 (Black, J., concurring).

108. R. DworkIN, supra note 101, at 88. See Wechsler, Towards Neutral Principles of Constitutional Law, 73 Harv. L. Rev. 1, 14-15 (1959). But see O.W. Holmes, The Common Law 35-36 (1881).

109. See R. DworkIN, supra note 101 , at 85 .

110. See notes $16-28$ and accompanying text supra.

111. See text accompanying notes 16-29 supra. The "instrumental" justification for judicial action in the present context is straightforward. Even if it is assumed that all imdividuals appreciated the benefits of shifting to a nondepletable source of energy, property owners in a planned development may still prohibit local installation of solar collectors which entail a perceived aesthetic injury. This happens because the burden, though perhaps tiny compared to solar benefits, is borne exclusively by the neighborhood, while benefits accrue at an unrelated scale (e.g., reduced air pollution, perhaps located far from the area; increased national security; an improved social legacy to future generations). A "free rider" problem is created; the neighborhood has no incentive to endorse solar energy since it will be able to enjoy the large-scale advantages resulting from the sacrifices of other locations. Under such circuinstances, rehance on a decentralized decisionmaking systein will insure socially irrational choices. To obtain socially sensible results, total social costs must be balanced against total social benefits. Legislative or judicial intervention might be a means to such a properly balanced choice.

112. While prosolar rhetoric can approach moral dimensions, see note 9 supra, arguments of an instrumental nature dominate both sides of the issue.

113. It is tempting to treat the principle/pohcy distinction as a path to a general theory of the pubhic pohcy doctrine, simce that doctrine clearly needs a general unifymg and delimiting rationale. The distimction, however, proves too plastic for such general rehance, since principles and pohicies can be recast fluidly in each other's terms. See Dworkin, supra note 101, at 22-23, 82 n. 1; Wellington, supra note 58, at 223-25. A general theory which accepts principles but rejects poli- 
As seen, however, reversal of covenants on these grounds is unacceptably "legislative" not because the policy is amoral, but rather because the court lacks an accountable source for the amoral policy. Should sucl a source exist, it would enable a court to apply amoral policy without exceeding this definition of the legitimate bounds of the judicial role. ${ }^{114}$ The California statute is one explicit source of such an

cies as admissible public policy considerations must first classify candidate considerations. This effort is thwarted because few considerations fit exclusively imto one category. For example, many morality rules are economically efficient and thus desirable for reasons of policy. See National Soc'y of Professional Eng'rs v. United States, 98 S. Ct. 1355, 1367 (1978) ("Ethical norms may serve to regulate and promote this [policy in favor of] competition . . . ."); Alchian \& Demsetz, Production, Information Costs and Economic Organization, 62 AMER. ECON. Rev. 777, 790-91 (1972); Arrow, The Organization of Economic Activity: Issues Pertinent to the Choice of Market Versus Non-Markel Allocation, in JT. ECON. Comm. 91st Cong., Ist Sess., The ANALYsis AND Evaluation of Public Expenditure: The PPB System 47, 69 (Jt. Comm. Print 1969); Schelling, supra note 51 , at 65 . Attempts to solve this problem by determining the "dommant" nature of the consideration are, in many instances, artificial and unconvincing. E.g., Wellington, supra note 58 , at 229-33.

Further, because the distinction between principles and policies represents one opmion about the appropriate limits of the judicial role, acceptance of the distinction thus is a matter of personal political and jurisprudential outlook. Opmions which hold a goal of principle-based adjudication to be less feasible or compelling may not find the distinction to be a sensible foundation for the public policy doctrine. See note 132 and accompanying text infra.

Even those who generally share a goal of principle-based adjudication may find that the distinction fails to isolate the essential characteristics of unacceptable "judicial legislation." See Coleman, Book Review, 66 CALIF. L. REv. 885, 904-13 (1978). If perceived judicial role himits are reached in fact only when the proposed policy consideration is insufficiently "well-cntrenched," $i d$. at 906 , or raises too many "questions of judicial competence," id. at 908, then the distinction's proscription of judicial policy usage fails as a general guide due to its overbreadth. See M. SHAPIRo, supra note 90, at 45-46, 52-54. That the solar policy is apt to fail even these narrower criteria, see notes 1 and 16 and accompanying text supra; notes 128-31 and accompanying text infra, simply yields a narrower explanation of why the present solar policy is too "legislative" for judicial use in resolving the covenant conflict.

114. See R. Dworkin, supra note 101, at 107-10. The presence of such an accountable policy source also eases judicial strain caused by the functional limitations of courts. Most significantly in the present context, an accountable and competent policy judgment reduces the need for courts themselves to consider and draw conclusions from a range of legislative facts. See $2 \mathrm{~K}$. DAVIs, ADMINISTRATIVE LAW TREATISE $\& 15.03$ (1958). For example, a key determination in the present dispute is a judgment about the importance to society of bcginning to rely on nondepletable energy resources. Sucl a judgment would entail determining the extent of remaining fossil fuel sources, their likely extraction timing and cost, the likely growth of future energy demand, the capability of nondepletable sources to meet this demand, etc. See note 17 and accompanying text supra. Determination of sucl factual matters would certainly tax the traditional factfindimg methods of adjudication. See, e.g., Boyer, Allernatives to Administrative Trial-Type Hearings For Resolving Complex Scientific, Economic, and Social Issues, 71 Mich. L. Rev. 111, 114-20 (1972); Sclultze, The Public Use of the Private Interest, HARPER's MAG., May 1977, at 43, 61. Contra, Wellington, supra note 58, at 240. Cf. Polsby, Policy Analysis and Congress, 18 Pub. PoL'Y 61, 6668 (1969) ("In sliort, Congress in the nonnal course of events gathers great amounts of information, processes this infornation according to reasonably well-known criteria, and matches what it learns against goals. That is, it conducts a tremendous amount of policy analysis.").

Other common capacity limitations are not as serious here, however, due to the nature of the covenant dispute. For example, another frequent complaimt is that adjudication tends to narrow disputes between parties to the resolution of a simgle controlling issue. In contrast, a planning 
accountable balancing of the conflicting interests. ${ }^{115}$ But a statute need not resolve a controversy in specific terms to fulfill this accountability function. Both courts and commentators have argued that statutes may serve as sources of law beyond their precise strictures. ${ }^{116}$ Thus, for covenant conflicts outside of California, this inquiry about the legitimacy of judicial intervention must consider whether existing statutes supply a sufficient basis for courts generally to protect solar development. ${ }^{117}$

\section{The Sufficiency of Present Solar Legislation as a Source of Accountability}

According to the viewpoint just explicated, a court should not overturn private arrangements to implement an amoral collective goal like solar developinent unless an institution competent to make the required value and interest trade-offs, i.e., the legislature, has determined the goal to be sufficiently important. Thus, while solar legislation need not overrule covenants explicitly, there must be some evidence that the legislative policy resolution enbodied in a particular statute considered and resolved this conflict in favor of solar policy. If there is no such evidence, this perspective loolds that the court lacks an accountable source for making the determination itself.

attitude which instead emphasizes the search for and evaluation of alternative policy solutions often is observed to be more appropriate in judging matters of social pohcy. E.g., D. HorowIrz, supra note 90 , at 284; M. ShaPIRo, supra note 90 , at $63,73-91$. This difficulty can be avoided in the present dispute. A judge could shift the search for alternative resolutions onto the litigants by conditioning any holding favoring solar energy on the lack of a showing by the covenant beneficiary that measures of reasonable cost were possible to reduce the collectors' aesthetic impact. While such a procedure would require a determination of "reasonable cost" that is a problem whenever a range of camouflage measures is possible. See note 32 supra. This balancing of the "reasonableness" of alternatives inay be difficult, but it is a task more related to the judicial role than is discovering alternatives.

Another area in which courts may be institutionally ill-suited to deal with questions of public pohicy is in the administration of remedies. In many policy roles, e.g., school desegregation, courts find that the policy solution requires an affirmative decree. The judiciary's weaknesses in formulating effective affirmative remedies, in forecasting likely responses to their decrees, and in overseeing remedial administration and implementation have been amply documented. See, e.g., D. HoROwITZ, supra note 90, at 92, 253, 262, 264. But see Wellington, supra note 58, at 240-41. These management problems are avoided here because covenants establish entitlements which, once defined, tend to be policed by the private parties themselves.

115. See note 14 supra.

116. See United States v. Little Lake Misere Land Co., 412 U.S. 580, 593 (1973) ("the inevitable incompleteness presented by all legislation means that interstitial federal lawmaking is a basic responsibility of the federal courts"); Uvited States v. Atlantic Mut. Ins. Co., 343 U.S. 236, 245 (1952) (Frankfurter, J., dissenting).

Using admiralty wrongful death decisions as an example, James Landis severely criticized common law inattention to basic policy considerations which motivated specific legislative action in 1934. See Landis, supra note 90, at 222 (1934). Thirty-five years later, his argunents about judicial neglect of statutory sources of law were vindicated in Moragne v. State Marine Limes, Inc., 398 U.S. 375, 388-93 (1970). See text accompanying notes 118-25 infra.

117. See notes $32-40$ and accompanying text supra. 
An illustration is helpful. In Moragne v. State Marine Lines, Inc. ${ }^{118}$ the United States Supreme Court reviewed a claim by the family of a seaman killed on duty within territorial waters. The basis of the cause of action was unseaworthiness, which was barred at common law when, as there, no statute specifically granted such a right. Because the older admiralty tort exemptions had been the subject of widespread legislative reversal, however, the Court was confronted with a conflict between the shipowner interests in traditional hability exemption and the seaman interest im recovery, an interest that had received widespread legislative endorsement. .

Two federal statutes were relevant but did not control the case. The Jones Act ${ }^{119}$ granted a neghigence action to the survivors of seamen, but did not create an unseaworthiness cause of action. Such a right was provided by the Death on the High Seas Act ${ }^{120}$ except when death occurred within territorial waters, as had happened in Morange. Thus, the plaintiff had no claim if the statutes were limited to their express provisions.

The Court noted that common law had refused to create such causes of action in general, but that "legislatures both here and in England [early on] began to evidence unanimous disapproval of the rule against recovery for wrongful death."121 Although no specific statute created a right of wrongful death action for maritime law, the "legislative establishment of pohicy [m favor of wrongful death actions] carries significance beyond the particular scope of each of the statutes involved." 222 The Court saw its problem as determining "whether Congress has given such a direction im its legislation granting remedies for wrongful deaths in portions of the maritime domain."123

By examining the conflict between hability and exemption which the Death on the High Seas Act had resolved, the Court decided that Congress had not intended to preclude the unseaworthiness claim within territorial waters. The extraterritorial limitation was explamable, not as a judgment that seamen should be limited in their allowable causes of action when within territorial limits, but by the fact that the state remedies which were left as controlling in these waters were "generally the same as-and in some respects perhaps more favorable than-that imposed by federal maritime law"124 at the time of the statute's enactment. Thus, Congress had "legislated only to the three-mile

\footnotetext{
118. 398 U.S. 375 (1970).

119. 46 U.S.C. $\$ 688$ (1976).

120. Id. $\$ \S 761-768$.

121. 398 U.S. at 389.

122. Id at 390 .

123. Id. at 393.

124. Id. at 399 .
} 
limit because that was the extent of the problem," 125 not because it had determined that seamen's rights versus shipowners' rights should be different when closer to shore. The Court concluded that later judicial developments which made the federal unseaworthiness claim a more attractive remedy than the previously preferable state negligence claims also should apply within territorial waters. ${ }^{126}$

In observing the Court's reasoning about the larger policy resolution embodied within the specific terms of the Death on the High Seas Act and the companion laws, it is important to see that extension of the statute's authority goes beyond its direct language but nevertheless stays within the more general trade-off between seamen's and shipowner's rights which Congress had already settled. ${ }^{127}$ The judicial problem was not one of deciding "how strong" a particular policy is and therefore how far the court should extend it, but rather of deciding whether the prior legislative resolution of the conflict at issue gave the plaimtiff a right.

This analysis applies to measuring the solar statutes as an accountable policy source. The issue is whether any present statute directly or inferentially makes the policy choice to grant the solar enthusiast a solar construction right that preempts any restrictive covenant.

- The present answer at the federal level is no. Federal bills certainly demonstrate a strong federal commitment to research, development, and demonstration of solar energy, and to a subsidization of some of its private costs. ${ }^{128}$ They do nothing, lowever, to resolve any property use conflicts that might arise. ${ }^{129}$ In the one instance where the laws make any reference to property rights at all, it is to suggest that such rights are to be preserved ratlier than overruled. ${ }^{130}$ Thus, while

125. Id. at 398.

126. When the Death on the High Seas Act was enacted in 1920 , recovery under the unseaworthiness claim "was an obscure and relatively little used remedy." Id at 398, quoting G. GiLMORE \& C. BLACK, THE LAW OF ADMIRALITY 315, 361 (1957). This was altered in 1944, however, when Mahnich v. Southern S.S. Co., 421 U.S. 96 (1944), changed the standard for unseaworthiness from due diligence to strict liability, thus making it a more attractive cause of action.

127. See R. Dworkin, supra note 101, at 109, 111 n.1; Landis, supra note 90, at 220, $224-25$.

128. See text accompanying notes $32-40$ supra.

129. The decision to spend tax revenue for any purpose does represent a resolution of the conflict between expenditure for that purpose and for all other possible purposes. This certainly is the resolution of a policy conflict, but it is not the conflict facing the court in the covenant case. A judge cannot reason that since the legislature spent money on solar research rather than on defense, for example, it has resolved the conflict of covenant enforcement and solar development. Unless the court can find in a legislative action the resolution of the specific policy conflict it faces, the court cannot use the legislature as an accountable authority for that dispute.

130. The Solar Energy Researcl, Developinent, and Demonstration Act, 42 U.S.C. $\$ \S 5551$ 5566 (1976), directs the Cliairman of the Solar Energy Policy Coordimation and Management Program to "develop and carry out a general plan for inventorying all forms of solar energy resources associated with Federal lands and (where consistent with property rights) non-Federal lands." Id. at $\S 5554(\mathrm{~b})(1)$ (einphasis added). While the legislative history does not provide any 
the situation may change with new legislation, there currently exists no federal authority sufficient to refuse restrictive covenant enforcement on the grounds of the public policy doctrine. With the exception of the California statute, the same situation prevails at the state level. ${ }^{131}$

In conclusion, despite a strong legislative commitment to solar energy, the accountable value resolution at the core of this policy is insufficient to justify judicial covenant annulment im terms of Dworkin's concept of adjudication. While other theories of adjudication may condone more instrumental reasoning and thus permit judicial definition and implementation of social goals-like that supporting solar energy-to a greater degree, ${ }^{132}$ case law generally is consistent with

insight into this rather ambiguous phrase, it evidently is intended to protect rather than abrogate existing property rights. This attitude is cousistent with another provision of the bill that directs the Chairman to study "incentives to promote broader utilization and consumer acceptance of solar energy technologies." Id. at § 5557(b). The latter provision was a conference substitute for a House amendment that would have established a solar energy incentives task force, inter alia, to research and investigate "social, legal, and common barriers to public acceptance and use of solar energy." [1974] U.S. Code CoNG. \& AD. News 5915, 5930. The concern with incentives imphes a desire to proinote voluntary acceptance of solar energy rather than a judgment that rapid development requires the involuntary submission of other interests.

131. See notes 14 and 44 supra.

A related point is whether other state courts should use an extrajurisdictional policy decision like the California statute as an accountable source. Commentary supports this idea. Gellhorn, supra note 85 , at 691 . Some decisions also support the possibility. Moragne v. State Marine Lines, Inc., 398 U.S. 375,390 (referring to the universal state passage of wrongful death statutes when determining whether a federal wrongful death action exists); Eyerınan v. Mercantile Trust Co., 524 S.W.2d 210, 217 (Mo. 1975) ("In the absence of guidance from authorities in its [sic] own jurisdiction, courts may look to the judicial decisions of sister states for assistance in discovering expressions of public policy.").

To be persuasive, however, this source would seen to require an overwhelming showing of a trend in extrajurisdictional policy. The Moragne court, for example, relied on unanimous passage of wrongful death actions at the state level and on two quite closely relatcd-though not controllimg-statutes at the federal level. Additionally, it would be inportant for a court to ascertam whether significant reasons prevented the policy's adoption in the home jurisdiction. See Moragne, 398 U.S. at 398 (concluding that statutory omission of the area in question was not causę by legislative desire for weaker rights in that area but because the area covered "was the extent of the problein"). Thus, the lone California statute seems to have too little force to serve as a policy source for a non-California court in presently resolving the conflict between restrictive covenants and solar development.

132. Wellington, for example, accepts the use of policy in adjudication, but considers it "lcgitimate only if two conditions are inet: The policy inust be widely regarded as socially desirable and it must be relatively neutral." Wellington, supra note 58, at 236 . He allows such uses ouly grudgimgly, however, simce he finds even policies satisfying his conditions to "tax the judicial process." Id. at 242.

Other viewpoints may find less danger in or alternative to pohicy-based adjudication. These perspectives presumably would be more willing to evaluate instrumentally the social importance of solar development, and perhaps to view the solar conflict itself in frankly political terms. For example, the dispute imight be seen as a clash of lifestyles, with solar support typifying a selfconsciously "progressive" or "environmentally concerned" class, and with opposition stemming from groups of different persuasions. The judicial result of a more political view of the conflict can push in different directions, depending on the pohtical values which are invoked to resolve it, 
Dworkin's postulated role boundary. For predictive purposes this suggests that (except in California) homeowners restrained by restrictive covenants will have a low probability of obtaining judicial relief under present statutory provisions.

III

\section{REMEDIAL COMPROMISE OF THE COMPETING INTERESTS: Covenant ENFORCEMENT Through DAMAges RATHER THAN INJUNCTIONS}

The preceeding analysis has led to the conclusion that courts are not- likely to use the solar policy to overturn covenant enforcement rights presently enjoyed by covenant beneficiaries. There reinains the issue of how such rights are to be enforced. Covenants are typically enforced by injunction, ${ }^{133}$ which completely bars the infringing land use. Some recent commentary has criticized universal employinent of this remedy, however, on that the grounds that it can lead to inefficient resolutions of land use disputes. ${ }^{134}$ From this perspective, the award of money damages may be a preferable solution because it would permit solar installation when the homeowner was willing to pay neighbors, homeowners associations, or other covenant beneficiaries for their judicially assessed injury. This section will examine the opportunity for and desirability of such remedial accommodations to the solar policy.

Classically, a court awards money damages whenever a plaintiff deinonstrates a legally cognizable injury or invasion of rights. The equitable remedy of injunction, to restrain installation or to remove the "invasion," is not similarly automatic, however, in that it depends upon the discretion of the court. In exercising their discretion, courts of equity have viewed injunctive relief as an "extraordinary" remedy available only under certain conditions. ${ }^{135}$ The courts "balance the conveniences" to the respective parties and issue an injunction only after finding that its resultimg benefits outweigh its consequential bur-

e.g., hostility to attitudes considered unconventional versus the desire to promote causes perceived as progressive.

133. Newman \& Losey, supra note 2, at 1344; Stoebuck, supra note 3, at 887.

134. See Ellickson, supra note 62; Ellickson, Suburban Growth Controls: An Economic and Legal Analysis, 86 Yale L.J. 385, 389, 509-11 (1977). But see Agins v. City of Tiburon, 23 Cal. 3d 605, 591 P.2d 514, 153 Cal. Rptr. 224, modified, 24 Cal. 3d 266, — P.2d -, - Cal. Rptr. - (1979); Polimski, supra note 62.

135. H. McClintock, Handbook of The Principles of Equity \& 22, at 47 (2d ed. 1948). Although injunctions to enforce covenants are "today routinely available on the theory that the legal remedy is imadequate to prevent future injury to unique property interests," Stoebuck, supra note 3 , at 887 , it would be erroneous to conclude that modern courts give injunctions as matters of right. See Yakus v. United States, 321 U.S. 414, 440, 442 (1944); Hecht Co. v. Bowles 321 U.S. 321, 328, 331 (1944). 
dens. ${ }^{136}$ This balancing is relevant in the present context because courts have long stated that they "go much further. to give and withhold relief in furtherance of the public interest than they are accustoned to go when only private interests are involved." 137

The "in furtherance of the public interest" logic could favor a damages remedy since this could increase the use of solar energy by facilitating the purchase of solar installation rights by homeowners from their neighbors, either individually or through a hoineowners association. In a theoretical world where individuals always could agree costlessly to undertake mutually beneficial transactions, enthusiastic loineowners slould be able to convince mildly disapproving neighbors to sell their covenant enforcement right irrespective of the remedy with which it would be enforced. ${ }^{138}$ In a realistic setting, however, the choice of reinedies might liave a very significant impact on the success of such attempted bargains through the allocation of transaction costs and bargaining risks. If a court enjoms covenant violation, the potential solar consumer inust assume the costs of reaching agreement with all of the relevant participants in the neighborhood covenant plan. Additionally, the solar consumer must bear the risk of bargaining breakdowns due to "strategic behavior" by the parties. Covenant enforcement by means of the dainages remedy avoids these problems by in effect "forcing a bargain" between the parties; the court permits installation by refusing the injunction, and it sets the contract price by assessing the level of inoney dainages owed to the neighbors. ${ }^{139}$ By assuring that some bargain will be reached and by shifting some negotiation cost away froin the hoineowner, one can conjecture that the damage remedy will lead to inore solar construction than the injunction case, where the homeowner inust bear all bargaining breakdown risks and negotiation costs. ${ }^{140}$

To counter this public interest argument in support of a dainages

136. See, e.g., Eccles v. People's Bank, 333 U.S. 426, 431 (1948); Di Giovami v. Camden Fire Ins. Ass'n, 296 U.S. 64, 70-71 (1935).

137. Virginian Ry. v. System Fed'n No. 40, 300 U.S. 515 (1937). See Vendo Co. v. LektroVend Corp., 433 U.S. 623, 645 \& n.1 (1977) (Stevens, J., dissenting).

138. See Coase, The Problem of Social Cost, 3 J. LAw \& Econ. 1 (1960). This assumes that the level of damages would be set to reflect accurately the neighbors' level of imjury.

139. A declaratory judgment action decided prior to actual construction will present the solar enthusiast with the court's determination of the appropriate level of compensation owcd to neighbors; the homeowner may then decide to pay or to forego the installation. If the action is brought affer the collector is installed, the solar enthusist will either have to pay or remove the collectors.

140. From a solar policy perspective, the most important effect of legal rules will be their effect on the private settlement of disputes, smce very few controversies will reach hitigation. It is diffcult to predict such effects, but it may be that hostile neighbors are more willing to compromise with potential solar consumers if it is certain that the covenant can be cnforced only to assess damages, based on the neighbors" ability to demonstrate an "objective" imjury. See notcs 142-47 and accompanying text infra. 
remedy, the neighbors and the homeowners association are likely to claim that this remedy is inadequate to protect their unique property interests. ${ }^{141}$ Taken literally, this argument seems implausible, smce it is difficult to believe that anyone would find the view of a solar collector so repugnant as to inake no sum of money-no nuatter how largesufficient to make one willingly accept the injury. The argunient seems inore reasonably understood as pointing to the evidentiary problenı of valuing the injury. In the present context, this problein would stem both from the lack of an authoritative market test of "objective" injury and froun the possible presence of additional "subjective" injury.

An "objective" valuation of the aesthetic injury caused by installation of a nearby solar collector could be obtained froln the resulting change in inarket value of the victim's property. ${ }^{142}$ Unfortunately, this is easier said than done. The only way actually to determine this inarket value is through sale of the property. This is usually an impractical solution even if the victim is willing to sell at a price which attracts a buyer, since it requires two observations-market value before and after the installation. Courts generally will have to resort to property assessors' value estimates, which are less reliable and pose the problem of conflicting testimony. ${ }^{143}$ Nevertheless, while the problem is real, it does not seem intolerable, since the law relies upon a factfinder's ability to sort out conflicting injury estimates on matters such as personal injury, which are even less susceptible to monetary valuation.

The second evidentiary problem is the valuation of "subjective"

141. See Stoebuck, supra note 3 , at 887 .

142. Market valuation is not strictly "objective" since it relies upon the subjective tastes and preferences of inarginal consumers. Nonetheless, if markets are workably competitive, they represent a more reliable and verifiable means of valuing damage than does the possibly self-serving property owner testimony.

In reality, if a solar installation increases the value of the installers own property, this may benefit neighboring property values in the same manner that the deterioration of one's property can drag down surrounding land prices. While this would be a question for resolution in a particular case, some general predictions can be ventured about the property value effect on the target property. First, the value of many solar honses sliould increase simply because they have two leating systems, including the conventional back-up system. This difference probably will prove more important than solar's higher purchase and installation cost as coinpared to conventional systems' higher operating costs, although this difference also should tend to increase the value of a solar-installed louse. Additionally, popular demand for solar-equipped residences may put a premium on these houses. See Marylander Marketing Research, Inc., supra note 11, at II-3: "A inajority of both professionals and consumers felt that SAGE [Solar Assisted Gas Energy] would enhance the sales potential of a residential structure. This perceived additional value associated with SAGE could be used for marketing both to builders and consumers." See also Thayer, Eyesore or Ideal? The Visual Ecology of Solar Architecture, presented at the HeLlosclenCE INSTITUTe ALternative ENERGy CONFERENCE 11-12 (Apr. 10, 1978) ("rapidly growing status" of solar devices may lead to imitation solar devices).

143. Property value estimates aimed at assessing the impact of a new technology like solar heating may be particularly inaccurate. As experience is gained with the technology, the problein slould diminish. 
aesthetic injury. Short of sale, there is no accurate method for determining the extent to which an assertedly ultrasensitive neighbor actually suffers from the collector view beyond the "average" estimate of injury which is incorporated in the market valuation. ${ }^{144}$ While one may sympathize with a property owner who is forced to undergo an unconsented and uncompensated imjury, the sympathy is undercut when the harm exceeds such "average" levels for several reasons. Most obviously, the only evidence of the asserted injury comes from the individual with imcentives to invent or magnify such a claim. Perhaps more broadly, there is a concern about the reasonableness of restraining land use on the basis of personal opinions that can be neither verified in fact nor bounded in scope. Nuisance law, for example, seeks to protect individuals of ordinary sensibilities only. ${ }^{145}$ Similarly, when covenants require approval of alterations by a body such as a homeowners association, ${ }^{146}$ a court will enforce the discretionary result of such a provision only if it is reasonable and in good faith. ${ }^{147}$ Hence, this argument for using injunctions and not damages also seems weak, though plausible.

In this context, the traditional equitable attention to the public interest might be decisive, smce the solar policy represents a strong "public interest" concern. ${ }^{148}$ There is doubt, however, about the doctrinal possibility, jurisprudential acceptability, and policy adequacy of resolving the present conflict by limiting covenant enforcement to an award of money damages.

First, it is not certain that a court has the power alternatively to enforce a subdivision covenant by granting a damages remedy, simce the question has not been considered often. Injunctions liave been the preferred remedy in covenant suits, and neither side generally has had an incentive to rebut the traditional arguments about the imadequacy of legal remedy in sucl situations. Consequently, covenant suits usually have involved only disputes over whether to grant or to withhold an injunction and not over whether an injunction is the appropriate remedy for a valid claim.

Theoretical analysis of the question fails to offer a definitive an-

144. This is similar to the valuation problem for public goods. See H. VARIAN, supra note S3, at 197-203.

145. See, e.g., Carter v. Johnson, 209 Cal. App. 2d 589, 26 Cal. Rptr. 279 (2d Dist. 1962); Ellickson, supra note 62 , at 733-36, 739-40.

146. See note 7 supra.

147. See, e.g. Hannula v. Hacienda Homes, Inc., 34 Cal. 2d 442, 447, 211 P.2d 302, 305-06 (1949); Donoghue v. Prynnwood Corp., 356 Mass. 703, 707, 255 N.E.2d 326, 329 (Mass. 1970); Annot., 40 A.L.R.3d 864, 879 (1971). The court, of course, determines the meaning of "reasonable." Seligman v. Tucker, 6 Cal. App. 3d 691, 697, 86 Cal. Rptr. 187, 191 (2d Dist. 1970). Cf. L. Sullivan, HaNDBOOK OF THE LAW OF ANTITRUST 249 (1977) (private imdustry self-policing standards must be "reasonable").

148. See notes $9-48,111$ and accompanying text supra. 
swer because the law has become confused. Covenant law developed in two historically distimct strains-legal and equitable ${ }^{149}$ - with the damages remedy probably confined to covenants of the former type. ${ }^{150}$ While these two forms once had distimct origms and theoretical traditions, modern courts have blurred the two doctrines ${ }^{151}$ for want of a substantive policy reason for adhering to the arcane distimctions. ${ }^{152}$ Probably the most accurate summary of the case law is that while precedent does not offer clear support for an exclusive dainage remedy for subdivision covenant violation, neither does it offer a significant barrier to a court convinced of the wisdom of such a course. ${ }^{153}$

Assuming that courts have the power to award damages when enforcing restrictive covenants, there is a further question of whether courts legitimately can use their discretion to act in the "public interest" as a means of choosing the reinedy most favorable to amoral policies like solar development. The earlier discussion suggesting that the use of the public policy doctrine to support such policies would be inappropriate ${ }^{154}$ also suggests that treatment of imstrumental policies as "public interest" factors affecting equitable discretion similarly should offend notions of legitimate behavior by courts.

Surprismgly enough, examination of the cases shows that the

149. Stoebuck, supra note 3, at 865-918. See Reno, supra note 64.

150. Stoebuck, supra note 3 , at 906.

151. See, e.g., Letteau v. Ellis, 122 Cal. App. 584, 588, 10 P.2d 496, 497 (1st Dist. 1932) ("In many, if not all, of the cases dealing with changed conditions, the terms [conditions, covenants, and mere restrictions] have been used with apparent disregard of the niceties of differentiation, and the reasons advanced would have application to a resulting situation, regardless of the means of its creation."). While this language has been termed "loose," Note, Covenants: Inapplicability of Section 1468 of the Civil Code of Covenants Contained in Grants, 28 CALIF. L. REv. 769, 770 (1940), the California Supreme Court later quoted it with approval in Fairchild v. Rains, 24 Cal. 2d 818, 151 P.2d 260 (1944) (Traynor, J., concurring). See also Richardson v. Callahan, 213 Cal. 683, 686, 3 P.2d 927, 929 (1931). Some modern commentators stress the importance of understanding the legal and equitable doctrines as analytically independent, yet concede that abandonment of distinctions has nearly come to pass. See, e.g., Stoebuck, supra note 3, at 863, 919-21; Newman \& Losey, supra note 2, at 1345.

Statutory provisions governing covenant enforcement do not seem to have affected the courts' traditional equitable approach in this area. See, e.g., Anthony v. Brea Glenbrook Club, $58 \mathrm{Cal}$. App. 3d 506, 130 Cal. Rptr. 32 (4th Dist. 1976). See also Arrache, Covenants: California's New Legislative Approach to Covenants Running With the Land, 9 SANTA ClaRA LAw. 285 (1969) (note that subsequent statutory amendments incorporated suggestions presented in id. at 295-97).

152. Ellickson, supra note 62 , at 715 , finds the rationale for the judicial distinctions "unfathomable." See Browder, Running Covenants and Public Policy, 77 MICH. L. REv. 12, 44 (1978) ("Property lawyers and teachers are accustomed to jibes from their colleagues about how outworn relics of the past still govern the law of property. . . . But otherwise discredited epithets still have some justification in the law on covenants running with the land.").

153. Statutory clarification of the courts' powcr to award damages for covenant violation would be an appropriate action for a legislature anxious to encourage solar imstallations but unwilling to follow the vigorous California approach. See notes 167-78 and accompanying text infra. The mildest course would be simply to authorize a damage award under such circumstances, while strongcr action would prcclude remcdies other than damages.

154. See notes 100-09 and accounpanying text supra. 
"pubhc interest" concerns voiced in the equitable balancing process are often of an amoral, instrumental, and goal-oriented nature. Such concerns include, for example, the importance of implementing a flood control plan, ${ }^{155}$ constructing a railroad beside a street, ${ }^{156}$ forcing a municipahty to construct a secondary sewerage treatment plant, ${ }^{157}$ determining the optimal location for railway depots, ${ }^{158}$ developing the George Washington Memorial Parkway, ${ }^{159}$ avoiding exposing subdivision residents to noxious odors, ${ }^{160}$ promoting the peaceable settlement of labor controversies, ${ }^{161}$ and protecting the "national economy from the disruptive influences of inflation in time of war."162

The imstrumental nature of such judicial reasoning is in tension with the rhetoric about role limitation and the goal of principle-based jurisprudence described earlier. ${ }^{163}$ It is superficial to attempt a reconciliation by arguing that here policy-based reasoning deals merely with reinedies rather than rights, since the meaning of a right is determined by the renedy available to enforce it. Nonetheless, it is the courts, whose role-based limitations are largely self-imposed, who evidently have not believed it improper to consider the impact of their choice of remedies upon the achievennent of goal-oriented collective objectives similar to the solar policy. While the difference in attitude can be understood in terins of the traditionally broad scope allowed to the exercise of equitable discretion, ${ }^{164}$ an historical explanation does hittle to reconcile such "legislative" action with the role-conscious rhetoric of modern inerged courts. This aspect of remedial design proposals should concern the proponents of principle-based jurisprudence and should trouble courts asked to tailor remedies on the basis of their evaluation of the importance of the solar policy.

The final doubt about the "damages only" resolution is that it simply inay be ineffective in promoting inuch additional solar use. Because remedial inanipulation assists only potential installations where the houneowner's private solar demand exceeds combined neighborlood opposition, it does not reach the certainly larger number of instances where the relevant private benefits are outweighed by the

155. Cubbins v. Mississippi River Comm'n, 204 F. 299, 305-08 (1913).

156. D. M. Osborne \& Co. v. Missouri Pac. Ry., 147 U.S. 248, 259-60 (1893).

157. City of Harrisonville v. Dickey Clay Mfg. Co., 289 U.S. 334, 337-41 (1933).

158. Beasley v. Texas \& Pac. Ry., 191 U.S. 492, $497-98$ (1903).

159. Greathouse v. Dern, 289 U.S. 352, 359-61 (1933).

160. Spur Indus., Inc. v. Del E. Webb Dev. Co., 108 Ariz. 178, 494 P.2d 700 (1972).

161. Virginian Ry. v. System Fed'n No. 40, 300 U.S. 515, 552 (1937).

162. Yakus v. United States, 321 U.S. 414, 440, 441 (1944); Hecht Co. v. Bowles, 321 U.S. 321, 329-31 (1944).

163. See note 90 and text accoinpanying notes 100-09 supra.

164. "Langdell once argued that, although there are rights at law, there is no such thing as 'a right in equity.' This is because, he contended, courts of law are bound by rules, while courts of equity proceed by discretion." Fuller, supra note 52, at 370 (footnote omitted). 
competing private costs, even though a social calculus might support a solar installation. ${ }^{165}$ Consequently, this pohcy may still result in too few solar installations. In fact, if potential solar consuiners are typically willing to pay a nnaximum which is less than the typical minimum required by neighbors for adequate coinpensation, then froin a solar policy standpoint the "damages only" resolution is a very sinall improvement upon flat injunctive covenant enforcement.

Reınedial manipulation imitially nnay appear attractive as a ineans of compromising coinpeting policies. ${ }^{166}$ After examining this particular compromise, however, it is hard to develop inuch enthusiasm for it since it strains against the previously identified limitations on the judicial role in order to achieve policy ends of dubious practical significance. Adequate resolution of the issue deinands legislative action.

\section{IV}

\section{The NeEd for Legislative Resolution of THE CONFLICT}

The preceding analysis has deinonstrated that constraints on the judicial role are apt to prevent courts from effectively overcoming the barrier to solar policy presented by restrictive covenants. Even the most active judicial role simply would limit covenant enforcennent to damages. This compromise still will result in too few solar installations from the viewpoint of society as a whole, since private arrangenents will not take into account solar energy's external benefits. ${ }^{167}$ Uncertainty about the parties' respective legal rights ${ }^{168}$ and the high costs of neighborhood-wide transactions to annul the covenant unay prevent solar installations even where the lone homeowner's personal demand for solar heating outweighs total neighborhood opposition or injury. A legislative resolution thus is required to give effect to the goal of shifting to a nondepletable energy base.

The legitimate rehance interest in covenant enforcement merits

165. See note 111 and text accompanying notes 11-14 supra. This disparity is offset to the extent that social subsidies are effective in increasing the private demand for solar energy, by means of solar tax credits, government subsidization of industry research and development costs, etc.

166. Cf. Coons, Approaches to Court Imposed Compromise-The Uses of Doubt and Reason, 58 Nw. U.L. REV. 750 (1964) ("when reason can produce no other conviction it ought to produce compromise"). If a damage remedy is found attractive, its administration would be aided by some procedural safeguards. A houneowners association which represents a neighborhood should be joined in the hitigation even if it was not previously involved in the particular dispute. Also, notice should be given to all parties in the neighborhood who inay be affected. Other rules for the administration of class action recoveries should not prove necessary in such disputes, however, since the damaged parties form a relatively small and identifiable class.

167. See note 111 and text accompanying notes 11-14 supra.

168. See text accoinpanying notes I49-53 supra. 
some recognition in a fair legislative solution. But an equitable compromise should discount coinpletely inost solar injuries provided that the solar enthusiast takes whatever aesthetically ameliorative measures are possible at reasonable cost. ${ }^{169}$ Further, while it is socially desirable to encourage innovation im solar technology, a reasonable legislative accommodation could require hoineowners to avoid those varieties which are particularly offensive to neighbors. ${ }^{170}$

The California legislation provides one such compromise. ${ }^{171}$ By voiding any covenant which "effectively prohibits or restricts the installation or use of a solar energy system," except "reasonable restrictions" whicl "do not significantly increase the cost of the system or significantly decrease its efficiency, or which allow for an alternative system of cost and efficiency," 172 the legislation seeks to balance the importance of the solar policy with recognition of neighborhood covenant interests.

This compromise reflects a legislative belief that some type of solar installation reasonably can be accommodated in every neighborhood. Where aesthetic restrictions seek to reduce a system's visual impact at a low dollar or efficiency cost (for example by placing collectors flush with a roof or hiding them with landscaping) the legislation permits such restrictions to be enforced. But requirements which drastically reduce the efficiency of a system (for example, by requiring that collectors be placed on the north side of a roof) or which require significant additional expense (for example, by demanding that a roof be rebuilt to conceal collectors) are unenforceable under the ternis of the law.

The apparent stringency that every neighborhood permit solar $\mathrm{m}$ stallations is mitigated by the law's definition of "comparable alternative" requirements as permissible "reasonable restrictions." This slould allow neighborloods to protect their views by forbiddmg atypical or expermiental types of solar systems which are unusually ugly. Judicial interpretation of this provision should sanction "comparable alternative" restrictions designed to preclude garage inonstrosities or experimental test facilities so long as such restrictions do allow for inore typical types of solar imstallations.

In general, this legislative coinpromise is admirable. ${ }^{173}$ By leaving

169. See note 72 supra.

170. For example, tracking collectors, OTA REPORT, supra note 3, at 246-48, and "reflector collectors," $i d$ at 261-83, are technologically advanced systems which some day might be used in residential installations. In many areas, however, their potentially large aesthetic impact could justify a legislative decision to insist on more traditional and less noticeable collectors.

171. See note 14 supra.

172. Cal. Civ. Code $\S 714$ (West Supp. 1978) (emphasis added).

173. The legislation does raise possible constitutional questions concerning the contracts clause of the United States Constitution and, in most states, a taking of property without just 
the term "significantly" undefined, however, the legislature creates a substantial degree of uncertainty about its exact resolution of the conflict, uncertainty which requires judicial interpretation for clarification.

One might react in two ways to such a lack of statutory specificity. First, one can view the statute as a legislative request that courts develop a new attitude towards covenants which, except in "extreme" cases, generally discounts their importance when they conflict with solar developments. The statute would not be a final policy resolution so inuch as an assignment of the balancing function to courts for fair caseby-case resolution, in the manner of delegation to an administrative agency. Lack of statutory specificity thus would not be a particular weakness since it would not disturb the law's main effect, that of negating stare decisis constraints and informing the judiciary of the new importance of solar development.

From a contrary perspective, the statute's generality raises two significant problems. The first concerns the statute's effectiveness in attaining its solar development goal. If legal uncertainty about the right to install a solar heater is resolved only after litigation in each particular case, this will create crippling transaction costs for most solar installations. The statute thus hinders efficient private resolution of individual conflicts by failing to clearly define entitlements. ${ }^{174}$

A vague statute poses a separate problem regarding the integrity of government institutions. If legislative failure to specify an exact policy trade-off stems inore from a desire to avoid confronting the conflict than from a concern to retain necessary flexibility in the application of the statute, then this dodging of an essentially legislative trade-off definition unay be considered irresponsible. ${ }^{175}$

Both of these objections are inet by defining the "reasonableness" of a restriction in clear quantitative terms, e.g., reasonable restrictions are those which do not increase the total cost of a solar energy system by more than ten percent. ${ }^{176}$ While a similar quantitative definition of reasonable efficiency coinpromises may not be so simple, every effort should be made to indicate the approximate weight of the policy tradeoff. ${ }^{177}$ Such action would add to the statute's credibility as well as its

compensation. See Southern Cal. Edison Co. v. Bourgerie, 9 Cal.3d 169, 507 P.2d 964, 107 Cal. Rptr. 76 (1973). Both of these possible defects appear to have been avoided by the nature of the problem and the legislation's concern with mandating only reasonable solutions. See Allied Structural Steel Co. v. Spannaus, 438 U.S. 234, 242-44, 250 (1978); Penn Central Transp. Co. v. City of New York, 438 U.S. 104, 123-38 (1978).

174. See note 50 supra.

175. Cf. A. Neale, The ANTitrust Laws of the U.S.A. 178-80 (2d ed. 1970) (explaining need for flexibility in outlawing "unfair methods of competition").

176. Such legislation could cover all expenses of this nature within any solar tax incentives offered by the state. See, e.g., Cal. Rev. \& TAX. CoDE $\$ 17052.5$ (West Supp. 1978).

177. Efficiency compares the total solar energy available to a system with the amount actually 
effectiveness.

While legislatures may devise other strategies, ${ }^{178}$ the California approach-particularly with the suggested modifications-currently provides the most equitable and effective means of implementing the solar policy. It thus merits the attention of other states.

\section{CONCLUSION}

Shifting energy reliance to nondepletable and benign sources may be critical for a nation which has exhausted a significant portion of the planet's energy resources in a blink of geologic time. Yet, if self-imposed judicial restraints are to be observed, this goal presently has received insufficient legislative clarification for courts to overturn covenant enforcement rights hindering its achievement. In contrast, and to soine extent contrary to such limitations, courts have been willing to further important instrumental goals by ineans of their choice of reinedies to enforce private rights that conflict with the achievement of those goals. This limited judicial effort to accomplish collective ends may represent the inost satisfactory solution where state legislatures have not yet addressed the covenant problem, but it places courts in an uncomfortable role in order to achieve a compromise of dubious practical significance.

The need for legislative action is plain. California's approach of voiding unreasonable restrictions, modified to define reasonability im clear quantitative terms, provides a fair policy trade-off designed by an accountable body.

The immediate setting of this conflict between public policy and private arrangeinents may be relatively transient. At some point the retrofit of solar systems on existing buildings will be surpassed by their construction as part of new buildings, where margimal architectural efforts may greatly reduce the aesthetic problem. Future collector designs perhaps inay becoine aesthetically inore acceptable as the industry continues to advance beyond the garage enthusiast stage. Basic aesthetic attitudes nay change. In a larger sense, lowever, the

consumed. See J. KRENZ, supra note 1, at 213-31. In practice, however, the quantitative measurement of changes in efficiency caused by particular camouflage measures would be complicated, even for the simpler active solar systems. See, e.g., OTA REPORT, supra note 3, at 303-26; CAL. Energy Resources Con. AND Dev. Comm. Alternatives Div., Guideline for CertificaTION OF SOlAR ENERGY EQUIPMENT 16, 38-39 (June 15, 1978). While not impossible, it is more difficult to measure efficiency for passive solar systems, because such measurement involves an analysis and prediction of the thermal characteristics of building design. These difficulties mean that any insistence upon measures requiring engineering caleulations will create counterproduetive transactions costs. Nevertheless, a quantitative percentage definition of "reasonable" based on estimated effects would still be useful in quantifying the extent of enforceable aesthetic restrictions.

178. See note 154 supra. 
problem is more permanent, due to the widespread and detailed use of private arrangements of all types and the ever more comprehensive nature of government policy concerns. These forces will require sensitivity from both courts and legislatures to means of compromise that not only strike an appropriate balance between the competing considerations but also result in an acceptable definition of the judicial role.

John Wiley*

* A.B. 1975, University of California, Davis; third-year student, Law \& Economics Program, Boalt Hall School of Law - University of California, Berkeley; Note \& Comment Editor, California Law Review. 